medRxiv preprint doi: https://doi.org/10.1101/2021.03.27.21254457; this version posted March 29, 2021. The copyright holder for this preprint (which was not certified by peer review) is the author/funder, who has granted medRxiv a license to display the preprint in perpetuity. All rights reserved. No reuse allowed without permission.

Midwifery and nurse staffing of inpatient maternity services - a systematic scoping review of associations with outcomes and quality of care

\author{
Corresponding Author \\ Lesley Turner \\ Senior Teaching Fellow \\ University of Southampton, School of Health Sciences \\ Highfield Campus, Southampton SO17 1BJ \\ lyt1g19@soton.ac.uk
}

\title{
Co-authors
}

Professor Peter Griffiths

Chair of Health Services Research,

University of Southampton, School of Health Sciences

National Institute for Health Research Applied Research Centre (Wessex)

Highfield Campus, Southampton SO17 1B]

Peter.Griffiths@soton.ac.uk

Dr Ellen Kitson-Reynolds

Principal Teaching Fellow

University of Southampton, School of Health Sciences

Highfield Campus, Southampton SO17 1B]

e.l.kitson-reynolds@soton.ac.uk

\section{CRediT roles}

Lesley Turner

Professor Peter Griffiths

Dr Ellen Kitson-Reynolds
Conceptualisation, Methodology, Investigation, Writing - original draft

Conceptualisation, Methodology, Writing - review and editing

Validation, Writing - review and editing 


\title{
Midwifery and nurse staffing of inpatient maternity services - a systematic scoping review of associations with outcomes and quality of care
}

\author{
Abstract \\ Objective \\ To undertake a scoping literature review of studies examining the quantitative association between \\ staffing levels and outcomes for mothers, neonates, and staff. The purpose was to understand the \\ strength of the available evidence, the direction of effects, and to highlight gaps for future research.
}

\section{Data Sources}

Systematic searches were conducted in Medline (Ovid), Embase (Ovid), CINAHL (EBCSCO), Cochrane Library, TRIP, Web of Science and Scopus.

\section{Study Selection and Review methods}

To be eligible, staffing levels had to be quantified for in-patient settings, such as ante-natal, labour/delivery or post-natal care. Staff groups include registered midwives, nurse midwives or equivalent, and assistant staff working under the supervision of registered professionals. Studies of the quality of care, patient outcomes and staff outcomes were included. All quantitative designs were included, including controlled trials, time series, cross-sectional, cohort studies and case controlled studies.

Data were extracted and sources of bias identified by considering the study design, measurement of exposure and outcomes, and risk adjustment. Studies were grouped by outcome noting the direction and significance of effects.

Results

The search yielded a total of 3280 records and 21 studies were included in this review. There were three randomised controlled trials, eleven cohort studies, one case control study and six cross sectional studies. Seventeen were multicentre studies and nine of them had over 30,000 participants.

Reduced incidence of epidural use, augmentation, perineal damage at birth, postpartum haemorrhage, maternal readmission, and neonatal resuscitation were associated with increased midwifery staff. Few studies have suggested a negative impact of increasing staffing rates, although a number of studies have found no significant differences in outcomes. Impact on the mode of birth were unclear. Increasing midwifery support staff was not associated with improved patient outcomes. No studies were found on the impact of low staffing levels for the midwifery workforce.

\section{Conclusions and Implications for practice}

Although there is some evidence that higher midwifery staffing is associated with improved outcomes, current research is insufficient to inform service planning. Studies mainly reported outcomes relating to labour, highlighting a gap in research evidence for the antenatal and postnatal periods. Further studies are needed to assess the costs and consequences of variations in maternity staffing, including the deployment of maternity care assistants and other staff groups.

\section{Keywords}

Midwife ; Nurse; Staffing; Workload; Workforce planning; Patient safety 


\section{Introduction}

Inpatient maternity services provide antenatal, intrapartum, and postnatal care for women and babies with additional needs, and for those choosing to give birth in a hospital environment. There is much variation in the staffing levels for these in-patient units (Zbiri et al., 2018; Zhou et al., 2019; NHS Digital, 2020). Maternity professionals have concerns about low staffing levels and report that this poses a threat to safety (Smith et al., 2009; Simpson et al., 2016). Staffing levels have been implicated in a number of near-miss cases and sub-optimal outcomes (Ashcroft et al., 2003). Problems with inadequate staffing were identified in over a quarter of stillbirths reported in the UK from 2015-2017 (Manktelow et al., 2017).

In order to inform workforce planning, managers need evidence based guidelines to inform their staffing decisions. One such guideline from the UK is the recommendation that women should receive dedicated care from one midwife during labour (Royal College of Obstetricians and Gynaecologists, 2007). Guidelines differ in other parts of the world, and California was one of the first states to mandate a staffing ratio of no more than 2 patients in active labour to 1 nurse (Coffman et al., 2002). Evidence underpinning this was sparse at this time, although a later Cochrane review confirmed that continuous support in labour (from hospital staff or birth supporters) was associated with a higher rate of vaginal birth, reduced caesarean section, reduced instrumental birth and improved Apgar scores (Hodnett et al., 2013; Bohren et al., 2017). A large number of women still receive labour care by a core team of midwives, who also deliver care in the antenatal and postnatal wards of the hospital (Care Quality Commission, 2020). This is despite mounting evidence to support the roll out of continuity of carer (Sandall et al., 2016) which offers benefits in terms of reduced rates of stillbirth, premature births and medical interventions.

The relationship between staffing and outcomes is important in determining the level at which harm can occur or the level at which there is no additional tangible benefit in deploying more midwives. This is important as cost-effectiveness must be considered due to the scarcity of resources and competing demands in health care. Poor staffing has been implicated in a number of error reviews and reports of near-misses in maternity care (Ashcroft et al., 2003; Karimi et al., 2016). The cost of litigation in maternity care is soaring (Tingle, 2016), and the human cost of poor outcomes is immeasurable. Complexity in maternity cases is increasing, so there is likely to be sustained demand for complex inpatient maternity care, requiring the expertise of core staff in these areas.

The impact of inadequate staffing is far-reaching and midwives have reported on the areas that have been missed due to high workload or time constraints (Simpson et al., 2016; Simpson et al., 2017; Haftu et al., 2019). This includes measuring vital signs, medicines administration, noting changes in acuity, response in emergencies and emotional support (Bick et al., 2014; Simpson et al., 2016). This can lead to reduced opportunities to identify deterioration and to rescue from preventable patient harm, such as fetal demise in labour, neonatal hypoglycaemia or infection (Simpson et al., 2017). One outcome that may be sensitive to staffing is the rate of term babies admitted to the neonatal unit (Clapp et al., 2019), causing separation from mothers and great cost to the health service.

A large body of evidence exists within nursing to suggest that a number of outcomes are sensitive to changes in staffing, such as falls, pressure ulcers and mortality (Patrician et al., 2011; Staggs et al., 2012; Griffiths et al., 2018). In an observational study of over 422,000 surgical patients in Europe, the increase in nurses workload by one patient increased the risk of a patient dying within 30 days by $7 \%$ (Aiken et al., 2014). There have been fewer studies in the midwifery literature, although a significant review was conducted by Bazian (2015) which summarised evidence from eight studies and highlighted a number of gaps in the research evidence. They found that most studies related to labour outcomes and mode of birth, although there was no consensus on the direction of effects for most maternal and fetal outcomes. This area is worthy of further exploration as a number of new 
studies have been published since the Bazian review (Bazian, 2015). Before future research is commissioned it is important to review the studies to date, and to establish what is known (and unknown) about the relationship between staffing and patient outcomes.

A further driver for interest in this area is the training and development of maternity support workers. Their role provides the opportunity for task-shifting and complementing the work of midwives. It is unclear whether the evidence supports the widespread development of these roles, although an evaluation by Griffin et al. (2012) suggests a potential positive impact on breastfeeding, parent education and discharge procedures. Preliminary work has been undertaken on the economics of skill mix in maternity care by Cookson et al. (2014) and Laliotis et al. (2018), although there is concern about the quality of data on effectiveness, due to the use of aggregate data to measure staffing and the potential for unmeasured confounding in observational studies.

\section{Methods}

The aim of this scoping literature review was to identify and summarise studies which examine the association between staffing levels of registered midwives and the outcomes for mothers and neonates. The purpose was to examine the strength of the available evidence, the direction of effects, and to highlight gaps for future research.

The review addressed the following specific questions.

What is the extent and nature of the body of knowledge relating midwifery staffing to outcomes, in terms of the number of studies, designs, methodology, participants, settings and outcomes investigated?

Is there an association between the midwifery staffing levels for in-patient services and outcomes and quality of care, and do outcomes differ when the proportion of registered staff to support workers varies? 


\section{Design}

A scoping literature review methodology was selected in order to summarize the breadth of the evidence from a range of sources (Levac et al., 2010). Unlike a systematic review, a scoping review allows researchers to identify all the relevant literature regardless of study design. A protocol was not registered in advance as this scoping review developed iteratively to discover the nature of the literature available.

\section{Search strategy}

Searches were completed in Medline (Ovid), Embase (Ovid), CINAHL (EBCSCO), Cochrane Library, TRIP, Web of Science and Scopus on $6^{\text {th }}$ April 2020. Search terms were entered as key words and subject headings, to identify primary research relating to staffing and maternity care (See Appendix 1 for full search strategy). No limitations were placed on the date of publication.

The reference lists of eligible studies were scanned to identify further references. All eligible studies were entered into the Cited Reference Search in Web of Science to identify citations and potential new primary studies in the same field.

\section{Study selection}

Studies were eligible for inclusion if they investigated the quantitative association between a measure of midwifery staffing levels and/or skill mix and outcome for mother baby, or staff members, costs or quality of care. All quantitative designs were included including controlled trials, time series, cross-sectional, cohort studies and case controlled studies. Studies on the effects of implementing changes to staffing levels or mix were included, as were studies on the effects of implementing a mandatory minimum staffing policy or a tool to measure demand and guide staffing decisions.

To be eligible for inclusion, staffing levels had to be quantified in measures such as staff per bed, staff to mother ratio, or hours per patient day. An assumption was made that continuous support from a midwife in labour was similar to a staffing ratio of 1:1, and therefore papers reporting staffing in this way were eligible for inclusion. Staff groups include registered midwives, nurse midwives or equivalent, and assistant staff working under the supervision of registered professionals. Studies reporting a quantitative measure of subjective staffing adequacy were included but purely qualitative studies were excluded.

Staffing in any or all inpatient settings were considered including ante-natal, labour/delivery and post-natal care. Studies which were based in neonatal units and midwifery community settings were excluded.

All references arising from the search were imported into Endnote $\mathrm{X9} \mathrm{TM}^{\mathrm{TM}}$ reference management software where duplicates were removed. Studies were screened and excluded if titles were unrelated to the subject area. The abstracts of 266 studies were read and studies excluded if it was clear that the inclusion criteria were not met by reading the abstract alone. Forty-six full text articles were screened against the inclusion criteria. All included papers were checked, and the decision verified by at least two reviewers. Of the excluded papers, double rating of a sample suggested a high level of agreement. Data charting was performed by one investigator.

Statistical meta-analysis was not attempted but all results were tabulated to show both the direction and statistical significance of the observed effects. From this a description of the overall pattern of results was derived. Sources of bias were identified by considering the study design, measurement of exposure and outcomes, and risk adjustment. 
medRxiv preprint doi: https://doi.org/10.1101/2021.03.27.21254457; this version posted March 29, 2021. The copyright holder for this preprint (which was not certified by peer review) is the author/funder, who has granted medRxiv a license to display the preprint in perpetuity.

All rights reserved. No reuse allowed without permission.

Figure 1: Outcome of search strategy

\section{PRISMA 2009 Flow Diagram}

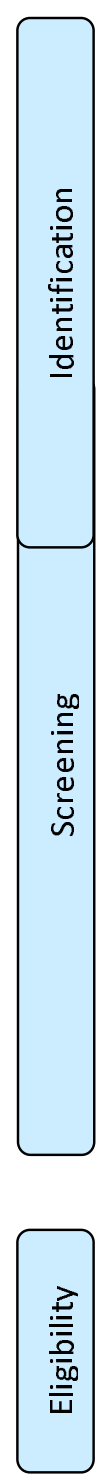

Records identified through database searching

$(n=3280)$
Additional records identified through other sources

$(n=23)$

Records after duplicates removed

$(n=2868)$
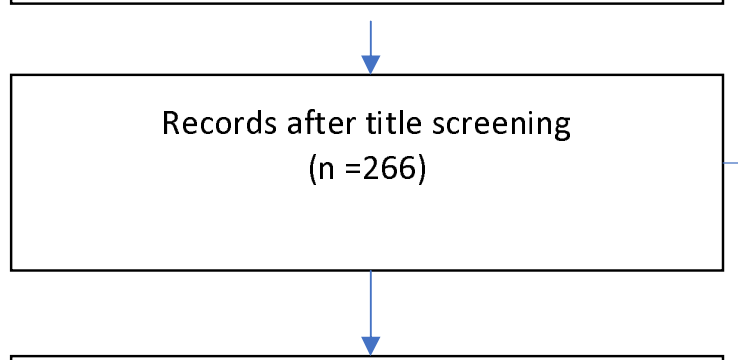

Records after abstracts screened

$(n=46)$

Records excluded

( $n=220$ )

( $n=2602$ )

Full-text articles excluded, with reasons

$(n=23)$

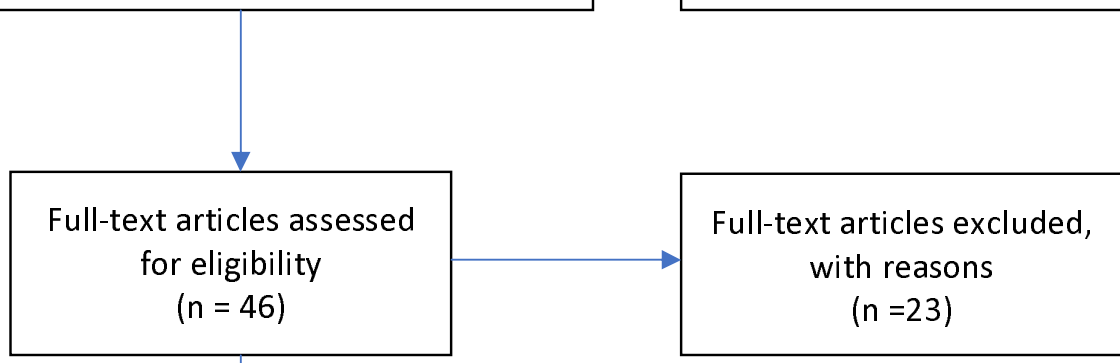

Papers included in review $(n=23)$ 


\section{Results}

\section{Summary of included studies}

The online searches yielded a total of 3280 records. The PRISMA flow diagram is shown in Figure 1 below. Twenty one separate studies were identified which were published from $1988-2020$. These studies are tabulated in detail in Appendix 2. Data were extracted from 23 papers as two studies were reported separately. One study was available as an abstract only (Mercer, 2016). There were three randomised controlled trials, eleven cohort studies, one case control study and six crosssectional studies.

Nine studies were conducted in the UK, and the remaining studies were conducted in USA, Canada, France, Italy, Indonesia, Korea, Thailand and Iran. Six studies included only participants at low risk of complications. Three studies included only complex cases such as women having postpartum haemorrhage (Prapawichar et al., 2020), those having oxytocin in labour (Clark et al., 2014) or caesarean section (Kim et al., 2016). The majority of studies (14/21) reported only outcomes relating to labour and birth. No studies of antenatal inpatient care were found, and there were four studies of postnatal care outcomes, including those studying readmission rates.

There were 17 multicentre studies and many were large. Nine studies had over 30,000 participants and five studies had over 400,000 participants. In terms of measurement of staffing, 16 studies used the term 'midwife' while others looked at staffing by 'nurses' or 'nurse-midwives' in a labour setting. Three studies also included the impact of health care assistant/support worker staffing, and eight studies also examined medical staffing in terms of obstetricians, anaesthetists or neonatal doctors.

\section{Quality of the evidence}

Three randomised controlled trials (Gagnon et al., 1997; Hodnett et al., 2002; Kashanian et al., 2010) compared patients all receiving one to one care in labour with usual staffing levels, although all had some limitations. Hodnett et al. (2002) excluded patients where one-to-one care was deemed medically necessary. Kashanian et al. (2010) included only 100 women and the usual labour care involved a lack of privacy, no birth companion and women were not permitted to eat and drink. The third RCT (Gagnon et al., 1997) was relatively small and incorporated other therapeutic measures along with the one-to-one care which limits the ability to assess the effects of the staffing ratio alone.

Of the eleven cohort studies, only the Tucker et al. (2003) study provided data on objective patient outcomes while also adjusting for baseline risk and other confounders. Other cohort studies considered care processes such as time to theatre transfer for caesarean section, quality of record keeping, mode of birth or labour interventions (Cerbinskaite et al., 2011; Knape et al., 2014; Rowe et al., 2014; Bailey et al., 2015; Zbiri et al., 2018). These outcomes may not translate directly into benefits for patients. The study by Clark et al. (2014) was conducted in a select patient group receiving oxytocin, limiting the generalisability of findings. The measurement of staffing was based on opinion, and the background risk was not adjusted for. The Dani et al. (2020) study did not measure staffing exposure directly and was at risk of bias due to differences in settings and patient acuity between the two groups. Cohort studies by Kim et al. (2016) and Stilwell et al. (1988) were deemed to be at high risk of bias in the assessment of staffing exposure and had limited risk adjustment. Mercer (2016) was published only as an abstract and therefore the methodology could not be scrutinised.

Of the six cross-sectional studies, four were large scale studies which used routine data to assess exposure to staffing and patient-centred outcomes such as perineal damage, maternal mortality, readmission rates, still birth and neonatal mortality (Joyce et al., 2004; Gerova et al., 2010; Sandall et 
medRxiv preprint doi: https://doi.org/10.1101/2021.03.27.21254457; this version posted March 29, 2021. The copyright holder for this preprint (which was not certified by peer review) is the author/funder, who has granted medRxiv a license to display the preprint in perpetuity. All rights reserved. No reuse allowed without permission.

al., 2014; Makhfudli et al., 2020). Other cross sectional studies focused on the outcome of mode of birth (Joyce et al., 2002; Gerova, 2014) or had a narrow focus on epidural use (Kpéa et al., 2015). All of these studies controlled for risk in terms of maternal age, deprivation, and some measures of clinical risk. These cross-sectional studies considered aggregate measures of staffing such as the number of midwives employed at institutional level or the number of midwives in relation to patients or births. This represents a major difficulty in determining that staffing exposure is causally linked to outcomes for patients, as the time period and fluctuating staffing exposure may not match patient stay. It also does not account for deployment of midwives within the service as some may have non-clinical roles. 
medRxiv preprint doi: https://doi.org/10.1101/2021.03.27.21254457; this version posted March 29, 2021. The copyright holder for this preprint (which was not certified by peer review) is the author/funder, who has granted medRxiv a license to display the preprint in perpetuity.

All rights reserved. No reuse allowed without permission.

\section{Maternal outcomes in relation to staffing}

Nine studies examined the outcomes for mothers after birth (Table 1). On the whole, most of these suggest improved outcomes where more staff were present. The outcomes studied included severe maternal outcome (death or near miss), perineal trauma, post-partum haemorrhage, maternal readmission, satisfaction, and maternal infection.

Delivery with bodily integrity and intact perineum were more common when more midwives were employed (Sandall et al., 2014). This finding of reduced perineal trauma was supported by studies by Gagnon et al. (1997) and Hodnett et al. (2002) although significance was not reached. In the case control study by Prapawichar et al. (2020), hospitals which had below the standard nurse midwife to patient ratio had significantly increased odds of postpartum haemorrhage OR $2.3(95 \% \mathrm{Cl} 1.08$ to $4.92, p=0.03$ ). Two studies found that maternal readmission was lower when more midwives or nurses were employed in the organisation (Gerova 2010, Kim 2015).

In contrast to this, the study by Clark et al. (2014) found opposite effects for rates of complications in their population of high risk women receiving oxytocin. The lack of risk adjustment in this study could not eliminate confounding by indication, that is higher risk women had higher staffing levels because of the increased risk. Makhfudli et al. (2020) found that the odds of a severe maternal outcome, as defined by World Health Organization (2019) was lower when women were admitted to units with higher nursing staffing (OR $0.48,95 \% \mathrm{Cl} 0.31$ to 0.74 ) but rates were increased in units where midwifery staffing was higher (OR $1.81,95 \%$ (Cl 1.07 to 3.06 ).

Table 1 : Maternal outcomes in relation to staffing

\begin{tabular}{|c|c|c|c|c|}
\hline Outcome measure & Favours more staff & $\begin{array}{c}\text { Point estimate } \\
\text { favours more staff } \\
\text { (NS) }\end{array}$ & $\begin{array}{c}\text { Point estimate } \\
\text { favours less staff } \\
\text { (NS) }\end{array}$ & Favours less staff \\
\hline $\begin{array}{l}\text { Severe maternal outcome } \\
\text { (death or near miss) }\end{array}$ & $\begin{array}{l}\text { Makhfudli } 2020 \\
\text { (nurses) }\end{array}$ & & & $\begin{array}{l}\text { Makhfudli } 2020 \\
\text { (midwives) }\end{array}$ \\
\hline Intact perineum/trauma & Sandall 2014 & $\begin{array}{l}\text { Gagnon } 1997 \\
\text { Hodnett } 2002\end{array}$ & & \\
\hline Delivery with bodily integrity & Sandall 2014 & & & \\
\hline Postpartum haemorrhage & Prapawichar 2020 & & & \\
\hline Composite healthy mother & & Sandall 2014 & & \\
\hline Lower Maternal readmission & $\begin{array}{l}\text { Gerova } 2010 \\
\text { Kim } 2015\end{array}$ & & & \\
\hline Satisfaction/preference & Hodnett 2002 & Sandall 2014 & & \\
\hline Multiple complications & & & & Clark 2014 \\
\hline Endometritis & & & Clark 2014 & \\
\hline Amnionitis & & & Clark 2014 & \\
\hline
\end{tabular}


medRxiv preprint doi: https://doi.org/10.1101/2021.03.27.21254457; this version posted March 29, 2021. The copyright holder for this preprint (which was not certified by peer review) is the author/funder, who has granted medRxiv a license to display the preprint in perpetuity.

All rights reserved. No reuse allowed without permission.

\section{Neonatal outcomes in relation to staffing}

Ten studies examined the outcomes for neonates (Table 2). Outcomes studied included Apgar scores, birth asphyxia, need for neonatal resuscitation, breastfeeding, admission to the neonatal unit, stillbirth, neonatal death and a composite measure entitled healthy baby. Other potentially important outcomes for babies including neonatal readmission, neonatal hypoglycaemia, sustained breastfeeding, jaundice, and weight loss were not studied.

Three studies report significantly improved outcomes which favour more staff, and one study shows results in the opposite direction. Dani et al. (2020) found higher breastfeeding rates with increased staffing ( $88 \%$ vs $78 \%, p=0.048$ ), although comparisons took place in two different settings. They also report lower Neonatal Unit admission (2\% vs $9 \%$ ), and this is supported by further studies by Hodnett et al. (2002) and Tucker et al. (2003), although these findings did not reach significance. Gagnon (1997) provides evidence to the contrary, with rates of neonatal unit admission of $7.2 \%$ vs $4.9 \%$, RR1.46 $(95 \% \mathrm{Cl} 0.67,3.18)$, thereby presenting a mixed picture for this outcome. Considering the overall pattern, 11 studies have point estimates in favour of more staff while four show results favouring less staff.

Of the higher quality studies (Tucker et al., 2003; Sandall et al., 2014), these suggest that higher staffing was associated with improved neonatal outcomes. Tucker et al. (2003) reported that fewer babies needed neonatal resuscitation using advanced measures (OR $0.97,95 \% \mathrm{Cl} 0.94,0.99$ ). This was also noted by Hodnett et al. (2002) although no risk adjustment was undertaken in this study.

Table 2 : Neonatal outcomes in relation to staffing

\begin{tabular}{|c|c|c|c|c|c|}
\hline Outcome measure & $\begin{array}{l}\text { Favours more } \\
\text { staff }\end{array}$ & $\begin{array}{l}\text { Point estimate } \\
\text { favours more } \\
\text { staff (NS) }\end{array}$ & $\begin{array}{l}\text { No difference } \\
\text { or no data on } \\
\text { direction }\end{array}$ & $\begin{array}{l}\text { Point estimate } \\
\text { favours less staff } \\
\text { (NS) }\end{array}$ & Favours less staff \\
\hline Apgar score & & $\begin{array}{l}\text { Tucker } 2003 \\
\text { Kashanian } 2010\end{array}$ & & & Gagnon 1997 \\
\hline Lower Birth asphyxia & & Clark 2014 & & Hodnett 2002 & \\
\hline Lower rates Neonatal resus & Hodnett 2002 & Tucker 2003 & & & \\
\hline $\begin{array}{l}\text { Lower rates Neonatal resus } \\
\text { (excluding bag/mask only) }\end{array}$ & Tucker 2003 & & & & \\
\hline Lower Stillbirth & & & Joyce 2004 & & \\
\hline Lower Neonatal death & & & $\begin{array}{l}\text { Joyce } 2004 \\
\text { Stilwell1998 }\end{array}$ & & \\
\hline Composite healthy baby & & Sandall 2014 & & & \\
\hline Exclusive breastfeeding & Dani 2020 & & & & \\
\hline Admission to Neonatal unit & Dani 2020 & $\begin{array}{l}\text { Hodnett } 2002 \\
\text { Tucker } 2003\end{array}$ & & Gagnon 1997 & \\
\hline Neonatal length of stay & & & & Hodnett 2002 & \\
\hline Perinatal complications & & & Mercer 2016 & & \\
\hline
\end{tabular}


medRxiv preprint doi: https://doi.org/10.1101/2021.03.27.21254457; this version posted March 29, 2021. The copyright holder for this preprint (which was not certified by peer review) is the author/funder, who has granted medRxiv a license to display the preprint in perpetuity.

All rights reserved. No reuse allowed without permission.

\section{Events during labour}

Ten studies examined events during labour in relation to staffing (Table 3). Outcomes studied included the quality of record keeping, continuous fetal monitoring in low risk women, fetal distress, augmentation of labour, epidural use, speed of theatre transfer for caesarean section, and length of labour. These care process measures are difficult to interpret as they may not translate into differences in patient outcomes. Many of the findings favour more staff, with seven comparisons reaching statistical significance in that direction. Ten further comparisons show non-significant results in favour of more staff. Three comparisons favour having less staff, although some of these result from subgroup analyses.

Fetal distress was lower in facilities that offered 1:1 care more frequently (Clark et al., 2014) and the completeness of the partogram improved (Bailey et al., 2015). Kpéa et al. (2015) found that if the midwifery workload was high, $58.3 \%$ of women had an epidural or spinal for pain relief, compared to $49.7 \%$ if the workload was not high (OR 1.1, 95\% $\mathrm{Cl} 1.0-1.2$ ). This finding was also supported by other studies, although non-significant effects were seen (Gagnon et al., 1997; Joyce et al., 2002; Rowe et al., 2014). Lower staffing was associated with higher augmentation rates, and this reached significance for multiparous women (Rowe et al., 2014). These findings suggest higher intervention rates when staffing levels fall, possibly representing a lack of support for women to manage pain or to facilitate progress of labour.

Cerbinskaite et al. (2011)studied the time taken to enter theatre for emergency caesarean section, and found this to be reduced when more midwives were present. For example, transfer time to theatre for grade 1 caesarean section was achieved within 15 mins for $81 / 82$ (99\%) cases where staffing was $1: 1$ or better, compared to $34 / 40(85 \%)$ when the ratio fell below this target.

Table 3 Events during labour in relation to staffing

\begin{tabular}{|c|c|c|c|c|}
\hline Outcome measure & Favours more staff & $\begin{array}{c}\text { Point estimate } \\
\text { favours more staff } \\
\text { (NS) }\end{array}$ & $\begin{array}{c}\text { Point estimate } \\
\text { favours less staff } \\
\text { (NS) }\end{array}$ & Favours less staff \\
\hline Completeness of partogram & $\begin{array}{l}\text { Bailey } 2015 \\
\text { (hrs 0-8 of shift) }\end{array}$ & $\begin{array}{l}\text { Bailey } 2015 \\
\text { (hrs 8-12 of shift) }\end{array}$ & & \\
\hline Completeness of note keeping & & $\begin{array}{l}\text { Bailey } 2015 \\
\text { (hrs 0-8 of shift) }\end{array}$ & $\begin{array}{l}\text { Bailey } 2015 \\
\text { (hrs 8-12 of shift) }\end{array}$ & \\
\hline Continuous fetal monitoring & Hodnett 2002 & & & \\
\hline Appropriate fetal monitoring & & $\begin{array}{l}\text { Tucker } 2003 \\
\text { low risk women }\end{array}$ & $\begin{array}{l}\text { Tucker } 2003 \\
\text { high risk women }\end{array}$ & \\
\hline Less Fetal distress & Clark 2014 & & & \\
\hline $\begin{array}{l}\text { Less oxytocin use / } \\
\text { augmentation }\end{array}$ & $\begin{array}{l}\text { Rowe } 2014 \text { in } \\
\text { multiparous }\end{array}$ & $\begin{array}{l}\text { Gagnon } 1997 \\
\text { Kashanian } 2010 \\
\text { Rowe } 2014 \text { in } \\
\text { primiparous }\end{array}$ & & \\
\hline $\begin{array}{l}\text { Time to delivery interval for } \\
\text { c-section }\end{array}$ & Cerbinskaite 2011 & & & \\
\hline Less Epidural use & Kpea 2015 & $\begin{array}{l}\text { Gagnon } 1997 \\
\text { Joyce } 2002 \\
\text { Rowe } 2014 \text { in } \\
\text { nulliparous } \\
\end{array}$ & & \\
\hline Shorter Length of labour & Kashanian 2010 & Gagnon 1997 & & \\
\hline
\end{tabular}


medRxiv preprint doi: https://doi.org/10.1101/2021.03.27.21254457; this version posted March 29, 2021. The copyright holder for this preprint (which was not certified by peer review) is the author/funder, who has granted medRxiv a license to display the preprint in perpetuity.

All rights reserved. No reuse allowed without permission.

\section{Mode of birth in relation to staffing}

Ten studies examined mode of birth as an outcome measure, examining rates of emergency caesarean section, instrumental birth and spontaneous vaginal birth (Table 4). The results were mixed, and no patterns emerged favouring more or less staff.

Measures of birth without assistance were defined differently in the studies, using the terminology 'normal birth' and 'spontaneous vaginal birth' at times. Within this theme, only Gerova (2014) found a significant association between increased staffing and more normal birth, while studies by Sandall (2014), Hodnett (2002) and Rowe (2014) offered inconclusive findings. An extension of this outcome 'straightforward birth' was used by Rowe (2014) to include unassisted birth with no serious perineal trauma or blood transfusion.

In terms of caesarean section rates, only two studies (Kashanian et al., 2010; Zbiri et al., 2018) found a positive association between more staff and reduced caesarean section rate. Rowe et al. (2014) found the opposite, in that understaffing was significantly associated with reduced caesarean section rates, and this was significant for nulliparous women. The majority of other studies examining this outcome found no significant differences (Gagnon et al., 1997; Hodnett et al., 2002; Joyce et al., 2002; Clark et al., 2014; Gerova, 2014; Sandall et al., 2014; Kim et al., 2016). All studies examining the effect of staffing on instrumental birth had non-significant findings and the directions of effect were not consistent (Joyce 2002, Gagnon 1997, Gerova 2014, Hodnett 2002, Rowe 2014).

Table 4 Mode of birth in relation to staffing

\begin{tabular}{|c|c|c|c|c|}
\hline Outcome measure & Favours more staff & $\begin{array}{l}\text { Point estimate } \\
\text { favours more staff } \\
\text { (NS) }\end{array}$ & $\begin{array}{l}\text { Point estimate } \\
\text { favours less staff } \\
\text { (NS) }\end{array}$ & Favours less staff \\
\hline Lower Caesarean birth rate & $\begin{array}{l}\text { Kashanian } 2010 \\
\text { Zbiri } 2018 \\
\text { (elective cs) }\end{array}$ & $\begin{array}{l}\text { Clark } 2014 \\
\text { Gagnon } 1997 \\
\text { Hodnett } 2002 \\
\text { Joyce } 2002 \\
\text { Sandall } 2014 \\
\text { (emergency) }\end{array}$ & $\begin{array}{l}\text { Gerova } 2014 \\
\text { Rowe } 2014 \text { in } \\
\text { multiparous } \\
\text { Sandall } 2014 \text { (elective) } \\
\text { Zbiri } 2018 \\
\text { (urgent or intrapartum } \\
\text { cs) }\end{array}$ & $\begin{array}{l}\text { Rowe } 2014 \text { in } \\
\text { nulliparous }\end{array}$ \\
\hline Lower Instrumental birth & & $\begin{array}{l}\text { Joyce } 2002 \\
\text { Hodnett } 2002 \\
\text { Rowe } 2014 \text { in } \\
\text { nulliparous } \\
\text { Knape } 2014 *\end{array}$ & $\begin{array}{l}\text { Gagnon } 1997 \text { Gerova } \\
2014 \\
\text { Rowe } 2014 \text { in } \\
\text { multiparous }\end{array}$ & \\
\hline $\begin{array}{l}\text { Increased Spontaneous vaginal } \\
\text { birth / Normal birth }\end{array}$ & Gerova 2014 & $\begin{array}{l}\text { Sandall } 2014 \\
\text { Rowe } 2014 \text { in } \\
\text { nulliparous }\end{array}$ & $\begin{array}{l}\text { Hodnett } 2002 \\
\text { Rowe } 2014 \text { in } \\
\text { multiparous }\end{array}$ & \\
\hline Increased Straightforward birth & & & $\begin{array}{l}\text { Rowe } 2014 \text { in } \\
\text { nulliparous }\end{array}$ & $\begin{array}{l}\text { Rowe } 2014 \text { in } \\
\text { multiparous }\end{array}$ \\
\hline
\end{tabular}

*Knape (2014) studied lower caesarean section or operative birth as one outcome 
medRxiv preprint doi: https://doi.org/10.1101/2021.03.27.21254457; this version posted March 29, 2021. The copyright holder for this preprint

(which was not certified by peer review) is the author/funder, who has granted medRxiv a license to display the preprint in perpetuity.

All rights reserved. No reuse allowed without permission.

\section{Effect of midwifery support worker staffing}

Three studies (Gerova 2014, Sandall 2014, Kim 2016) reported on the addition of health care support workers and relationship with outcomes. Gerova (2014) found that increases in health care assistants were not significantly related to the probability of emergency section $(O R=0.99,95 \% \mathrm{Cl}$ 0.96-1.03), instrumental birth (OR=1.003, 95\% Cl 0.96-1.05) or normal birth $(\mathrm{OR}=0.99,95 \% \mathrm{Cl} 0.95$ 1.03). Kim (2016) evaluated the impact of increasing the total number of nurses, both licenced and unlicensed. As the total workforce increased, this was not significantly associated with the risk of readmission within 30 days (RR1.01, 95\% $\mathrm{Cl} 1.0,1.02$ ).

Sandall (2014) found no significant differences in outcomes for increasing support worker staff in the adjusted overall analysis. Sensitivity analyses were performed in different risk groups and parity. Increasing support workers was associated with an increase in birth with bodily integrity for lowerrisk women (OR 1.04) but not for higher-risk women (OR 0.96). The chances of the healthy mother outcome being met were reduced when the number of support workers increased, irrespective of parity (ORs range from 0.87 to 0.93 ). Support worker staffing levels were associated with a reduced healthy baby outcome (ORs range from 0.90 to 1.00 for women of different parity). When considered together, the above findings do not highlight substantial benefits or detriments for increasing support worker numbers in the workforce.

\section{Effects on staff delivering care}

There were no published studies which reported a numeric association between staffing levels and measures of staff wellbeing in the maternity services. No studies were found relating staff retention, job satisfaction or sickness absence to staffing levels.

\section{Economic analyses}

Economic analyses were included in primary studies by Clark (2014) and Sandall (2014). Clark (2014) noted that considerable investment would be required to implement one-to-one care for patients undergoing oxytocin induction or augmentation within the USA. They found insufficient evidence of benefit in their trial to justify the additional costs.

Sandall (2014) modelled staffing in relation to cost per birth and found that higher midwifery staffing was associated with increased delivery costs. The relationship was not strong, and this variable plus Trust size and case mix accounted for only $17 \%$ of cost variation between Trusts. Cookson et al. (2014) provided an economic impact assessment based on the Sandall (2014) data above. In their calculations, an increase in 1 Full Time Equivalent midwife per 100 births provided an incremental cost effectiveness ratio of $£ 85,560$ per additional healthy mother and $£ 193,426$ per mother with bodily integrity. 


\section{Discussion}

The body of evidence on midwifery staffing and outcomes is small and provides mixed results. While there is some evidence that increased staffing improves outcomes for mothers and neonates, this predominantly relates to labour care and outcomes within the first hour after birth. Some of the variables measured in the studies are measures of care and it is unclear whether they would translate into improved outcomes.

For the mother, increased staffing was associated with reduced epidural rates, augmentation, perineal damage during the birth, post-partum haemorrhage, and maternal readmission. For neonates, increased staffing was associated with higher breastfeeding rates and reduced need for neonatal resuscitation. Staffing may influence the quality of care in labour, as there was some evidence of improved record keeping and timeliness of emergency caesarean section. Increased attention by staff may reduce the risk of negative outcomes, while also supporting coping mechanisms in labour and supporting infant feeding.

Very few studies have suggested a negative impact of increasing staffing rates, although a large number have found no significant differences. It is possible that other prognostic variables such as patient demographics, clinical risk, or other therapeutic interventions may have overshadowed any effects of variation in staffing in these studies. A significant limitation of the available evidence is that many of the studies have not measured staffing levels directly, which has an unknown effect on the accuracy of findings. A lack of risk adjustment is a major potential source of bias within many of the studies presented.

Results for mode of birth are hard to interpret as studies are not in agreement on whether rates of spontaneous birth, instrumental birth or caesarean section are associated with staffing levels. Higher staffing levels can result from the assessed need for more staff to care for high risk mothers. This tends to mask the beneficial effect of higher staffing. Assisted birth may be entirely appropriate for high risk cases to prevent adverse maternal and fetal outcomes so should not be considered to be a detrimental outcome (Kirkup, 2015; Dietz et al., 2016).

This review contributes to the debate on whether staffing ratios should be recommended in maternity care, including all in-patient wards. It is notable that staffing ratios for labour ward, antenatal and postnatal areas have been recommended in Australia (Australian Nursing Midwifery Foundation, 2015) and in the USA (Association of Women's Health Obstetric Neonatal Nurses, 2010). In the UK, guidance states that a systematic process is used to calculate total midwifery staff, incorporating historical data and predicted demand (National Institute for Health and Care Excellence, 2015). Birthrate Plus is one such tool for workforce planning, which is based on indicators of need in the population, while facilitating one to one care in labour (Ball et al., 2015). The tool does not collect data on outcomes, and therefore the adequacy of recommended resources cannot be evaluated. The impact of reducing or increasing staffing on outcomes is a pertinent question, especially as resources are scarce and staffing decisions should maximise cost-utility.

Understaffing may result from the inability to employ and retain registered staff (Heinen et al., 2013). This may result in the recruitment of alternative staff to complement existing midwives. This scoping review has found only three studies relating the number of support staff to patient outcomes. Outcomes were not improved by the addition of support workers, and Sandall et al. (2014) noted reductions in the composite outcome of healthy mother and healthy baby as the number of support workers increased. This fits with recent research in the nursing literature suggesting detrimental effects of diluting skill mix or having more or less nursing assistants than the average level (Aiken et al., 2017; Griffiths et al., 2019). 
Makhfudli et al. (2020) found that increasing nursing staffing was associated with less risk of maternal death or severe maternal outcomes, but the same was not true for midwives. It is possible that midwives were allocated the most complex obstetric cases who had a higher background risk for poor outcomes, or that nurses had improved training in preventing escalation of potentially life threatening conditions. The skill mix of the maternity workforce is changing, and additional skills are needed to care for women and babies with complex care needs and co-morbidities. The survey by Dent (2020) found that in the UK, healthcare providers were employing a variety of personnel to support midwifery services, including theatre nurses, obstetric nurses, nursery nurses, maternity care assistants and breastfeeding supporters. The contribution of each of these staff groups towards outcomes is unclear. These initiatives may be driven by necessity rather than optimal workforce planning.

No research studies were found examining associations between staffing numbers and the wellbeing of midwives. In an online survey of almost 2000 midwives by Hunter et al. (2019), perceived inadequacy of resources was the strongest predictor of work-related burnout. This may lead to staff attrition (Heinen et al., 2013), which is costly, not only for the employer but also considering the cost of training each midwife. The State of the World's Midwifery report highlighted voluntary attrition as one of the ten essential areas for workforce planning (Lopes et al., 2017). Challenges in recruitment and attrition have been described as a gathering storm especially in the light of increased demands and complexity (Royal College of Midwives, 2017).

It is important to note that most studies have been conducted on the labour ward/delivery suite, with a dearth of studies in antenatal and postnatal wards. Escalation plans often involve redeploying staff from these areas in order to meet need on the labour ward (Royal College of Midwives, 2016) and if they are not well staffed at the outset this may lead to critical shortages. In future, more resources may be deployed in the community as Renfrew et al. (2014) recommend a change in focus from the recognition and treatment of pathology for the minority, to providing skilled care for all. With a finite number of mid wives available, this may lead to difficult choices in the distribution of staff.

\section{Strengths and limitations}

In this scoping review, literature searching was completed in a systematic way, however, there may be undetected studies in the grey literature or in press that have not been accessed. The eligibility screening was not performed independently for all the papers, so it remains possible that some excluded papers might have been included by another reviewer. The high levels of agreement obtained on samples means that it is unlikely that this would make a substantial change to the overall number of included studies or the conclusions about the body of literature as a whole. Although major methodological issues have been discussed, the quality of the evidence has not been rigorously evaluated, which is consistent with the scoping review methodology. This means that poorer quality studies have been included, and these findings are more prone to bias.

\section{Recommendations for further research}

Further evidence is needed so that policy makers can make informed decisions about staffing levels and configurations, and the likely impact on outcomes. High quality research is needed to clarify the direction and strength of effects. Studies should examine a range of outcomes in addition to those on labour ward. These could include maternal mental health, neonatal weight loss, jaundice, sustained breastfeeding, and neonatal readmission following discharge home. Support worker contribution and the impact on workforce wellbeing also requires further research. Improved attempts should be made to measure staffing at a ward level or individual patient level if possible. The impact of different workforce configurations and staff groups should be considered. It is 
medRxiv preprint doi: https://doi.org/10.1101/2021.03.27.21254457; this version posted March 29, 2021. The copyright holder for this preprint

(which was not certified by peer review) is the author/funder, who has granted medRxiv a license to display the preprint in perpetuity.

All rights reserved. No reuse allowed without permission.

important that future studies adjust for underlying risk as well as other predictive factors such as parity, gestational age, pre-existing conditions, and socioeconomic status. Economic studies could model health care costs in terms of staffing numbers, but also potential cost-savings related to intervention rates in labour, readmissions and the cost of advanced neonatal care or maternal morbidity.

\section{Conclusion}

This scoping review has found some evidence of a positive association between staffing levels and improved outcomes for women and neonates. The evidence is not conclusive and is limited by the methodological quality of studies. Further research is needed so that service providers can predict the impact of changes to skill mix and staffing levels on a wide range of patient outcomes. 
medRxiv preprint doi: https://doi.org/10.1101/2021.03.27.21254457; this version posted March 29, 2021. The copyright holder for this preprint

(which was not certified by peer review) is the author/funder, who has granted medRxiv a license to display the preprint in perpetuity.

All rights reserved. No reuse allowed without permission.

\section{APPENDIX 1 : Search strategy for Medline Ovid}

(adapted for other online databases using exploded MeSH headings as appropriate)

1 childbirth.ab,ti.

2 birth.ab,ti.

3 labour.ab,ti.

4 newborn.ab,ti.

5 neonate.ab,ti.

6 mother-newborn.ab,ti.

7 mother-neonate.ab,ti.

8 caesarean.ab,ti.

9 postnatal.ab,ti.

10 postpartum.ab,ti.

11 "care after birth".ab,ti.

12 "care following birth".ab,ti.

13 maternity.ab,ti.

14 maternal.ab,ti.

15 midwifery.ab,ti.

16 midwives.ab,ti.

17 midwife.ab,ti.

18 exp labor, obstetric/ or exp parturition/

19 exp midwifery/ or exp obstetric nursing/

201 or 2 or 3 or 4 or 5 or 6 or 7 or 8 or 9 or 10 or 11 or 12 or 13 or 14 or 15 or 16 or 17 or 18 or 19

21 "staffing ratio".ab,ti.

22 "nurse to patient ratio".ab,ti.

23 understaffing.ab,ti.

24 staffing.ab,ti.

25 workload.ab,ti.

26 manpower.ab,ti.

27 "skill mix".ab,ti.

28 "skill-mix".ab,ti.

29 "work pressure".ab,ti.

30 "patient ratio* ".ab,ti.

31 "short staffing".ab,ti.

32 "midwife to patient ratio".ab,ti.

33 exp Health Workforce/

3421 or 22 or 23 or 24 or 25 or 26 or 27 or 28 or 29 or 30 or 31 or 32 or 33

35 case-control studies/ or cohort studies/ or controlled before-after studies/ or cross-sectional studies/or historically controlled study/ or interrupted time series analysis/

36 follow-up studies/ or longitudinal studies/ or prospective studies/or retrospective studies/

3735 or 36

3820 and 34 and 37 
APPENDIX 2 : Tabulation of studies

\begin{tabular}{|c|c|c|c|c|c|c|}
\hline $\begin{array}{l}\text { Author and } \\
\text { date }\end{array}$ & Design & $\begin{array}{l}\text { Participants and } \\
\text { Setting }\end{array}$ & Measurement of staffing & Outcome measures & $\begin{array}{l}\text { Potential confounders } \\
\text { measured and included in } \\
\text { analysis }\end{array}$ & Results \\
\hline $\begin{array}{l}\text { Bailey } 2015 \\
\text { (UK) }\end{array}$ & $\begin{array}{l}\text { Cohort study - } \\
\text { prospective. Single } \\
\text { centre }\end{array}$ & $\begin{array}{l}\text { Records from } 70 \\
\text { consecutive women } \\
\text { admitted to labour } \\
\text { ward. Records } \\
\text { available for } 61 \text { of } \\
\text { them who went into } \\
\text { labour }\end{array}$ & $\begin{array}{l}\text { Ratio of women to midwives } \\
\text { on labour ward for each } 4 \\
\text { hour block of time }\end{array}$ & $\begin{array}{l}\text { Composite record keeping } \\
\text { score, Quality of the } \\
\text { partogram recordings. } \\
\text { Stratified by } 4 \text { hour block } \\
\text { (beginning, middle, end of } \\
\text { shift). No neonatal } \\
\text { outcome measures. }\end{array}$ & $\begin{array}{l}\text { No risk adjustment for } \\
\text { potential confounders in the } \\
\text { analysis. Presented results } \\
\text { separately for beginning, } \\
\text { middle and end of shifts } \\
\text { (stratified reporting) }\end{array}$ & $\begin{array}{l}\text { The quality of partogram completion decreased } \\
\text { as workload increased (ratio of women to } \\
\text { midwives) and this effect was significant in the } \\
\text { first } 4 \text { hours and second } 4 \text { hours of the shift but } \\
\text { not in the last } 4 \text { hours. Correlation coefficient } \\
\text { was } 0.76 \text { ( } p<0.05 \text { ) in first } 4 \text { hours of shift, } 0.84 \text { in } \\
4-8 \text { hours ( } p<0.01 \text { ), and } 0.54 \text { in } 8-12 \text { hours of the } \\
\text { shift ( } p>0.05 \text { ). The scores for the composite } \\
\text { measure of notekeeping were not affected by the } \\
\text { ratio of women to midwives. Correlation } \\
\text { coefficients were } 0.14 \text { ( } p>0.05 \text { ) in first } 4 \text { hours, } \\
0.65 \text { ( } p>0.05 \text { ) in } 4-8 \text { hours and }-0.61 \text { ( } p>0.05 \text { ) in } 8 \text { - } \\
12 \text { hours of the shift. }\end{array}$ \\
\hline $\begin{array}{l}\text { Cerbinskaite } \\
2011 \text { (UK) }\end{array}$ & $\begin{array}{l}\text { Cohort study - } \\
\text { prospective. Single } \\
\text { centre }\end{array}$ & $\begin{array}{l}5167 \text { births, delivery } \\
\text { suite in UK, excluded } \\
\text { elective caesarean } \\
\text { section. Study of } 755 \\
\text { emergency c- } \\
\text { sections. }\end{array}$ & $\begin{array}{l}\text { Number of qualified midwives } \\
\text { on shift, number of labouring } \\
\text { women on labour ward, } \\
\text { labouring woman to midwife } \\
\text { ratio }\end{array}$ & $\begin{array}{l}\text { Decision to delivery interval } \\
\text { within } 30 \text { mins, transfer } \\
\text { time to theatre within } 15 \\
\text { mins. } \\
\text { No neonatal outcome } \\
\text { measures. }\end{array}$ & None & $\begin{array}{l}\text { Transfer time to theatre for grade } 1 \mathrm{c} \text {-sections } \\
\text { within } 15 \text { mins was achieved for } 81 / 82(99 \%) \\
\text { cases where staffing } 1: 1 \text { or better, compared to } \\
34 / 40(85 \%) \text { when ratio fell below } 1: 1 \text { ( } p<0.001) \text {. } \\
\text { For grade } 2 \mathrm{c} \text {-sections this was achieved for } \\
155 / 168(92 \%) \text { within } 15 \text { mins with } 1: 1 \text { staffing or } \\
\text { better, compared to } 29 / 43(67 \%) \text { when staffing } \\
\text { ratio less than } 1: 1 \text { ( } p<0.001) \text {. Grade } 1 \text { caesareans } \\
\text { were performed with a decision to-delivery } \\
\text { interval below } 30-\text {-minutes were } 77 / 82(94 \%) \text { if } \\
1: 1 \text { care or better staffed, compared to } 22 / 40 \\
(55 \%) \text { born when the ratio was lower than } 1 \\
\text { midwife: } 1 \text { woman ( } p<0.001) \text {. For Grade } 2 \\
\text { caesareans, rates of delivery within } 30 \text { mins were } \\
90 / 168(54 \%) \text { when } 1: 1 \text { care or better, compared } \\
\text { to } 5 / 43(12 \%) \text { if ratio less than } 1: 1 \text { ( } p<0.001) \text {. }\end{array}$ \\
\hline
\end{tabular}




\begin{tabular}{|c|c|c|c|c|c|c|}
\hline $\begin{array}{l}\text { Author and } \\
\text { date }\end{array}$ & Design & $\begin{array}{l}\text { Participants and } \\
\text { Setting }\end{array}$ & Measurement of staffing & Outcome measures & $\begin{array}{l}\text { Potential confounders } \\
\text { measured and included in } \\
\text { analysis }\end{array}$ & Results \\
\hline $\begin{array}{l}\text { Clark } 2014 \\
\text { (USA) }\end{array}$ & $\begin{array}{l}\text { Cohort study- } \\
\text { retrospective, } \\
\text { routine data. } \\
\text { Multi centre }\end{array}$ & $\begin{array}{l}101,777 \text { women } \\
\text { receiving oxytocin } \\
\text { for labour induction } \\
\text { or augmentation }\end{array}$ & $\begin{array}{l}\text { Facilities divided into four } \\
\text { groups based on the } \\
\text { frequency with which each } \\
\text { facility provided } 1: 1 \text { nurse } \\
\text { staffing for such patients } \\
\text { during } 2010 \text { (0 to } 25 \%, 26 \text { to } \\
50 \%, 51 \text { to } 75 \% \text {, or }>75 \% \text { ). } \\
\text { Based on opinion of nurse } \\
\text { leader. }\end{array}$ & $\begin{array}{l}\text { Fetal distress, caesarean } \\
\text { delivery, chorioamnionitis, } \\
\text { endomyometritis, and a } \\
\text { composite of adverse } \\
\text { events based on coding. } \\
\text { Birth asphyxia. }\end{array}$ & None & $\begin{array}{l}\text { Reference group are hospitals providing } 1: 1 \text { care } \\
76 \%-100 \% \text { of time or more. Odds of birth } \\
\text { asphyxia } 0.78(95 \% \mathrm{Cl} 0.61-1.01) \text { for } 51-75 \% \\
\text { group, } 1.05(95 \% \mathrm{Cl} 0.79-1.39) \text { for } 26-50 \% \text { and } \\
1.01(95 \% \mathrm{Cl} 0.81-1.26) \text { for } 0-25 \% \text { group. Higher } \\
\text { staffing ratios was associated with more } \\
\text { caesarean births ( } \mathrm{p}<0.0001) \text {. Odds of primary } \\
\text { caesarean } 0.95(95 \% \mathrm{Cl} 0.91-0.99) \text { for } 51-75 \% \\
\text { group, } 0.89(95 \% \mathrm{Cl} 0.85-0.94) \text { for } 26-50 \% \text { and } \\
1.06(95 \% \mathrm{Cl} 1.02-1.10) \text { for } 0-25 \% \text { group. Higher } \\
\text { staffing ratios was associated with more overall } \\
\text { complications ( } \mathrm{p}=0.002) \text {. Odds of overall } \\
\text { complications } 0.66(95 \% \mathrm{Cl} 0.62-0.70) \text { for } 51-75 \% \\
\text { group, } 0.88(95 \% \mathrm{Cl} 0.83-0.95) \text { for } 26-50 \% \text { and } \\
0.79(95 \% \mathrm{Cl} 0.75-0.83) \text { for } 0-25 \% \text { group. Fetal } \\
\text { distress was lower in facilities that offered } 1: 1 \\
\text { care more frequently (p<0.0001). Odds of fetal } \\
\text { distress } 1.05(95 \% \mathrm{Cl} 0.99-1.11) \text { for } 51-75 \% \\
\text { group, } 1.08(95 \% \mathrm{Cl} 1.01-1.15) \text { for } 26-50 \% \text { and } \\
1.18(95 \% \mathrm{Cl} 1.12-1.24) \text { for } 0-25 \% \text { group. Includes } \\
\text { modelling of cost data. }\end{array}$ \\
\hline $\begin{array}{l}\text { Dani } 2020 \\
\text { (Italy) }\end{array}$ & $\begin{array}{l}\text { Cohort study - } \\
\text { retrospective. } \\
\text { Multi centre }\end{array}$ & $\begin{array}{l}\text { Healthy infants born } \\
\text { after uncomplicated } \\
\text { pregnancy, vaginal } \\
\text { delivery without any } \\
\text { labour analgesia. } \\
110 \text { in Midwife led } \\
\text { Centre and } 110 \text { in } \\
\text { Obstetric led centre }\end{array}$ & $\begin{array}{l}\text { Comparison of } 2 \text { centres with } \\
\text { different midwifery staffing } \\
\text { ratios. Participants self } \\
\text { selected to attend either } \\
\text { centre. } \\
\text { Centre } 1 \text { (midwifery led in- } \\
\text { hospital centre) staffing ratios } \\
\text { of } 1: 2.5 \text { or } 1: 5 \text { depending on } \\
\text { time of day. } \\
\text { Centre } 2 \text { (obstetric led) ratios } \\
\text { of } 1: 7,1: 9 \text { or } 1: 15 \text { depending } \\
\text { on time of day }\end{array}$ & $\begin{array}{l}\text { Exclusive breastfeeding rate } \\
\text { at discharge, rates of } \\
\text { admission to neonatal unit, } \\
\text { length of stay }\end{array}$ & $\begin{array}{l}\text { Gestational age, Birthweight, } \\
\text { Length, Head circumference, } \\
\text { Apgar score, cord ph, weight } \\
\text { loss, bilirubin levels, sodium } \\
\text { levels, and need for } \\
\text { phototherapy. Unclear which } \\
\text { factors were entered into the } \\
\text { logistic regression analysis. }\end{array}$ & $\begin{array}{l}\text { Exclusive breastfeeding rate at discharge higher } \\
\text { in midwifery led unit with more staff ( } 88 \% \text { vs } \\
78 \%, \mathrm{P}=0.048) \text {. Mixed breastfeeding rate at } \\
\text { discharge was lower ( } 12 \% \text { vs } 20 \%, \mathrm{p}=.048) \text { in } \\
\text { infants born in the midwife- than in the } \\
\text { obstetrician-led centre. Admission rate to } \\
\text { neonatal unit was lower in the midwifery unit- } \\
\text { than in the obstetric area ( } 2 \% \text { vs } 9 \%, \mathrm{p}=0.017) \text {. } \\
\text { Length of stay was } 2.6 \text { days }(+/-0.8) \text { in midwifery } \\
\text { unit and } 3.1 \text { days }(+/-1.8) \text { in obstetric unit, } \\
\mathrm{p}=0.008 . \text { logistic regression analysis showed that } \\
\text { birth in the midwife-led unit increased the } \\
\text { likelihood of exclusive breastfeeding (OR } 2.04 \text {, } \\
95 \% \mathrm{Cl} 1.07-3.92 \text { ). Birth in the midwife-led } \\
\text { centre did not affect the duration of stay in } \\
\text { hospital (OR } 95 \% \mathrm{Cl} 0.81,95 \% \mathrm{Cl} 0.51-1.23 \text { ). }\end{array}$ \\
\hline
\end{tabular}




\begin{tabular}{|c|c|c|c|c|c|c|}
\hline $\begin{array}{l}\text { Author and } \\
\text { date }\end{array}$ & Design & $\begin{array}{l}\text { Participants and } \\
\text { Setting }\end{array}$ & Measurement of staffing & Outcome measures & $\begin{array}{l}\text { Potential confounders } \\
\text { measured and included in } \\
\text { analysis }\end{array}$ & Results \\
\hline $\begin{array}{l}\text { Gagnon } \\
1997 \\
\text { (Canada) }\end{array}$ & $\begin{array}{l}\text { Randomised } \\
\text { controlled trial. } \\
\text { Single centre }\end{array}$ & $\begin{array}{l}413 \text { nulliparous } \\
\text { women, }>37 \text { weeks, } \\
\text { singleton pregnancy } \\
\text { in labour. } \\
\text { Experimental group } \\
\text { ( } n=209) \text {, } \\
\text { Control ( } n=204) . \\
\text { Excluded high risk } \\
\text { women and those } \\
\text { with cervical } \\
\text { dilatation over } 4 \mathrm{~cm} \text {. }\end{array}$ & $\begin{array}{l}\text { One-to-one care consisted of } \\
\text { the presence of a nurse during } \\
\text { labour and birth using defined } \\
\text { supportive techniques. } \\
\text { Alternative is usual care, } \\
\text { where nurses assigned to two } \\
\text { patients at a time, normally } \\
\text { one in early labour and the } \\
\text { other near delivery, no } \\
\text { defined labour support } \\
\text { techniques. }\end{array}$ & $\begin{array}{l}\text { Defined by medical record } \\
\text { review. } \\
\text { C-section. } \\
\text { Secondary outcomes : Use } \\
\text { of oxytocin, labour } \\
\text { duration, epidural use, } \\
\text { instrumental birth, perineal } \\
\text { trauma } \\
\text { Neonatal outcomes : } \\
\text { Admission to NICU, Apgar } \\
\text { score (secondary outcomes) }\end{array}$ & None (RCT) & 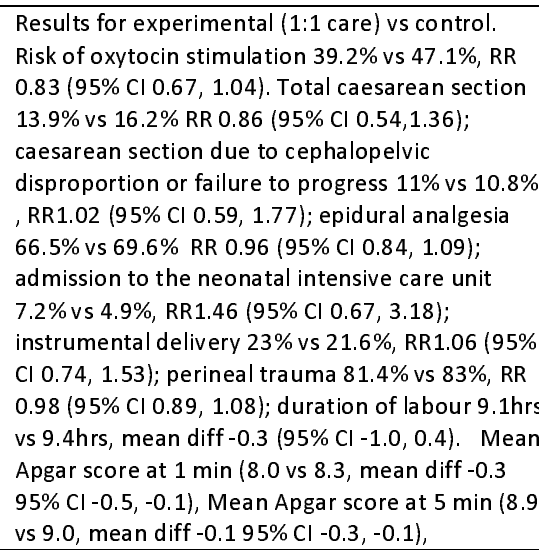 \\
\hline $\begin{array}{l}\text { Gerova } 2010 \\
\text { (UK) }\end{array}$ & $\begin{array}{l}\text { Cross sectional } \\
\text { study, routinely } \\
\text { collected data. } \\
\text { Multi centre }\end{array}$ & $\begin{array}{l}615,042 \text { mothers } \\
\text { giving birth in } 144 \\
\text { Trusts (out of } 150 \\
\text { Trusts that provide } \\
\text { maternity care in } \\
\text { England) }\end{array}$ & $\begin{array}{l}\text { NHS workforce statistics, } \\
\text { Maternity matters } \\
\text { benchmarking dataset. } \\
\text { Midwife FTE-birth r99atio. } \\
\text { Also included other staff } \\
\text { groups - medical staff, nurses, } \\
\text { nursery nurse, healthcare } \\
\text { assistants }\end{array}$ & $\begin{array}{l}\text { Maternal readmission } \\
\text { within } 28 \text { days, collected at } \\
\text { Trust level. } \\
\text { No neonatal outcome } \\
\text { measures. }\end{array}$ & $\begin{array}{l}\text { Risk adjustment performed at } \\
\text { patient level to include age of } \\
\text { mother; ethnicity; Carstairs } \\
\text { deprivation index; Charlston } \\
\text { co-morbidity index; delivery } \\
\text { type; professional delivering; } \\
\text { number of admissions in the } \\
\text { previous } 12 \text { months; pre- and } \\
\text { post-birth length of stay. }\end{array}$ & $\begin{array}{l}\text { Higher numbers of midwives FTE per births were } \\
\text { associated with a lower probability of } \\
\text { readmission, after adjustment for risk, Coefficient } \\
\text { B }-4.81(95 \% \mathrm{Cl}-4.87 \text { to- } 4.75, p<0.0001) \text {. A higher } \\
\text { ratio of consultant obstetrician FTE to midwives } \\
\text { FTE was associated with a lower probability of } \\
\text { readmission (Coefficient B }-3.56(95 \% \mathrm{Cl}-3.61 \text { to - } \\
3.52, p>0.001) \text {. Support worker staffing ratios } \\
\text { not included in regression model although data } \\
\text { was collected. }\end{array}$ \\
\hline
\end{tabular}




\begin{tabular}{|c|c|c|c|c|c|c|}
\hline $\begin{array}{l}\text { Author and } \\
\text { date }\end{array}$ & Design & $\begin{array}{l}\text { Participants and } \\
\text { Setting }\end{array}$ & Measurement of staffing & Outcome measures & $\begin{array}{l}\text { Potential confounders } \\
\text { measured and included in } \\
\text { analysis }\end{array}$ & Results \\
\hline $\begin{array}{l}\text { Gerova } 2014 \\
\text { (UK) }\end{array}$ & $\begin{array}{l}\text { Cross sectional } \\
\text { study, routinely } \\
\text { collected data. } \\
\text { Multi centre }\end{array}$ & $\begin{array}{l}261,481 \text { deliveries in } \\
143 \text { NHS trusts for } \\
\text { emergency } \\
\text { caesarean section } \\
\text { and instrumental } \\
\text { deliveries; and } \\
214,949 \text { deliveries in } \\
129 \text { NHS trusts for } \\
\text { normal birth. } \\
\text { Women aged 15-44, } \\
\text { who were } \\
\text { nulliparous and had } \\
\text { a term (>=37 weeks), } \\
\text { singleton, live birth. }\end{array}$ & $\begin{array}{l}\text { Maternity Workforce Dataset } \\
\text { and Hospital Episode Statistics }\end{array}$ & $\begin{array}{l}\text { Mode of birth. } \\
\text { No neonatal outcome } \\
\text { measures. }\end{array}$ & $\begin{array}{l}\text { Adjusted for maternal age, } \\
\text { ethnicity, deprivation (IMD), } \\
\text { clinical composite risk (NICE } \\
\text { 2007), gestational age and } \\
\text { birth weight. The sample was } \\
\text { homogeneous for parity, } \\
\text { singleton/live births and at } \\
\text { term deliveries (gestational } \\
\text { age }>37 \text { weeks). }\end{array}$ & $\begin{array}{l}\text { Standardized midwives } \mathrm{FTE} / \text { birth ratio was } \\
\text { positively related to the probability of normal } \\
\text { birth (coeff } 0.55, \mathrm{OR}=1.06,95 \% \mathrm{Cl} 1.01-1.11) .1 \mathrm{SD} \\
\text { increase in } \mathrm{FTE} \text { midwives increased the odds of } \\
\text { normal birth for low risk women by } 7.6 \% \\
\text { (OR=1.08, } 95 \% \mathrm{Cl} 1.02-1.14 \text { ). Standardized } \\
\text { midwives } \mathrm{FTE} / \text { birth ratio was not significantly } \\
\text { related to the probability of emergency section } \\
\text { (coeff-0.28, OR=0.97, } 95 \% \mathrm{Cl} 0.93-1.02 \text { ). } \\
\text { Standardized midwives } \mathrm{FTE} / \text { birth ratio was not } \\
\text { significantly related to the probability of } \\
\text { instrumental birth (coeff }-0.51, \mathrm{OR}=0.95,95 \% \mathrm{Cl} \\
0.9-1.01 \text { ). The study did not find any statistically } \\
\text { significant relationship between healthcare } \\
\text { assistants and birth outcomes. Standardized } \mathrm{HCA} \\
\mathrm{FTE} / \text { birth ratio was not significantly related to the } \\
\text { probability of emergency section (coeff }-0.08, \\
\text { OR=0.99, } 95 \% \mathrm{Cl} 0.96-1.03 \text { ), probability of } \\
\text { instrumental birth (coeff } 0.03, \mathrm{OR}=1.003,95 \% \mathrm{Cl} \\
0.96-1.05 \text { ), or probability of normal birth (coeff- } \\
0.009, \mathrm{OR}=0.99,95 \% \mathrm{Cl} 0.95-1.03 \text { ). }\end{array}$ \\
\hline $\begin{array}{l}\text { Hodnett } \\
2002 \text { (USA } \\
\text { Canada) }\end{array}$ & $\begin{array}{l}\text { Randomised } \\
\text { controlled trial. } \\
\text { Multi centre }\end{array}$ & $\begin{array}{l}6915 \text { women who } \\
\text { had a live singleton } \\
\text { fetus or twins, were } \\
34 \text { weeks gestation } \\
\text { or more. Randomly } \\
\text { assigned to } \\
\text { continuous labour } \\
\text { support by a } \\
\text { specially trained } \\
\text { nurse ( } n=3454 \text { ) } \\
\text { during labour or to } \\
\text { usual care ( } n=3461) \text {. } \\
\text { Setting: Thirteen } \\
\text { hospitals }\end{array}$ & $\begin{array}{l}\text { Continuous labor support = } \\
\text { nurse was expected to } \\
\text { provide continuous support to } \\
\text { the woman for a minimum of } \\
80 \% \text { of the time from } \\
\text { randomization to delivery (to } \\
\text { allow for meal } \\
\text { breaks/emergencies). Usual } \\
\text { care = time depended on } \\
\text { stage of labour, the condition } \\
\text { of the mother and fetus, and } \\
\text { the nurses' workload }\end{array}$ & $\begin{array}{l}\text { Caesarean delivery rate. } \\
\text { Secondary outcomes : } \\
\text { mode of birth, epidural, } \\
\text { perineal trauma, length of } \\
\text { labour, feeling of control, } \\
\text { postnatal depression. } \\
\text { Neonatal : Apgar score, } \\
\text { need for resuscitation, need } \\
\text { for nursery care, length of } \\
\text { stay. Extracted from } \\
\text { medical records. }\end{array}$ & None & 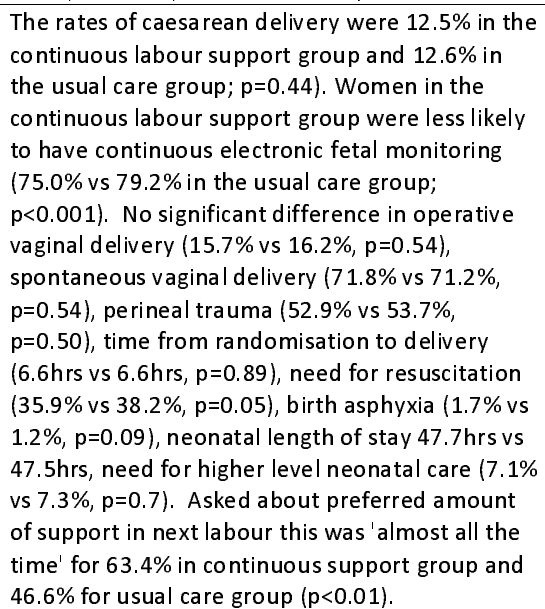 \\
\hline
\end{tabular}




\begin{tabular}{|c|c|c|c|c|c|c|}
\hline $\begin{array}{l}\text { Author and } \\
\text { date }\end{array}$ & Design & $\begin{array}{l}\text { Participants and } \\
\text { Setting }\end{array}$ & Measurement of staffing & Outcome measures & $\begin{array}{l}\text { Potential confounders } \\
\text { measured and included in } \\
\text { analysis }\end{array}$ & Results \\
\hline $\begin{array}{l}\text { Joyce } 2002 \\
\text { (UK) }\end{array}$ & $\begin{array}{l}\text { Cross sectional } \\
\text { study. Multi centre }\end{array}$ & $\begin{array}{l}540,834 \text { births, all } \\
\text { births in } 65 \text { hospitals }\end{array}$ & $\begin{array}{l}\text { Hospital level data. Nationally } \\
\text { held data on hospital staffing } \\
\text { levels. Number of midwives } \\
\text { per } 1000 \text { deliveries calculated }\end{array}$ & $\begin{array}{l}\text { Mode of birth and epidural } \\
\text { use in labour. No neonatal } \\
\text { outcome measures }\end{array}$ & $\begin{array}{l}\text { Adjusted for demographic } \\
\text { factors known to be associated } \\
\text { with perinatal outcomes; } \\
\text { maternal age, birthweight and } \\
\text { multiple births. }\end{array}$ & $\begin{array}{l}\text { Midwifery staffing was not significantly } \\
\text { associated with caesarean section rate ( } B=-0.117 \text {, } \\
p=0.181 \text { ) or instrumental delivery rate ( } B=-0.087 \text {, } \\
p=0.105 \text { ) in the simple linear regression. } \\
\text { Midwifery staffing was negatively correlated with } \\
\text { epidural rates ( } B=-0.532, p=0.049 \text { ) in simple linear } \\
\text { regression. In the multifactorial analysis this } \\
\text { effect on epidural rate was due to social class } \\
\text { demography between the units, rather than } \\
\text { midwifery staffing (coefficient, } C l \text { and } p \text { value not } \\
\text { presented). }\end{array}$ \\
\hline $\begin{array}{l}\text { Joyce } 2004 \\
\text { (UK) }\end{array}$ & $\begin{array}{l}\text { Cross sectional } \\
\text { study. Multi centre }\end{array}$ & $\begin{array}{l}540,834 \text { births, all } \\
\text { births in } 65 \\
\text { maternity units }\end{array}$ & $\begin{array}{l}\text { Hospital level data. Nationally } \\
\text { held data on hospital staffing } \\
\text { levels. Number of midwives } \\
\text { per } 1000 \text { deliveries calculated }\end{array}$ & $\begin{array}{l}\text { No maternal outcome } \\
\text { measures. } \\
\text { Still birth, neonatal } \\
\text { mortality. }\end{array}$ & $\begin{array}{l}\text { The following were entered } \\
\text { into the multiple regression } \\
\text { analysis: staffing rates } \\
\text { (paediatricians, obstetricians, } \\
\text { midwives), facilities (consultant } \\
\text { sessions, delivery beds, special } \\
\text { care baby unit, neonatal } \\
\text { intensive care unit cots), } \\
\text { interventions (vaginal births, } \\
\text { caesarean sections, forceps, } \\
\text { epidurals, inductions, general } \\
\text { anaesthetic), parental data } \\
\text { (parity, maternal age, social } \\
\text { class, deprivation, multiple } \\
\text { births) }\end{array}$ & $\begin{array}{l}\text { Midwifery staffing (midwives per } 1000 \text { deliveries) } \\
\text { was not a significant predictor variable for } \\
\text { stillbirth (B } 0.012, p=0.65 \text { ) or neonatal mortality } \\
\text { (B }-0.012, p=0.50 \text { ) in the simple linear regression. } \\
\text { Data not presented for multiple regression model } \\
\text { for midwifery staffing. }\end{array}$ \\
\hline $\begin{array}{l}\text { Kashanian } \\
2010 \text { (Iran) }\end{array}$ & $\begin{array}{l}\text { Randomised } \\
\text { controlled trial. } \\
\text { Single centre }\end{array}$ & $\begin{array}{l}100 \text { nulliparous } \\
\text { women. } \\
\text { Experimental group } \\
\text { ( } \mathrm{n}=50 \text { ) continuous } \\
\text { support in labour, } \\
\text { Control group ( } \mathrm{n}=50 \text { ) } \\
\text { no continuous } \\
\text { support. Inclusion } \\
\text { criteria were } \\
\text { nulliparous women } \\
\text { (low risk women), } \\
\text { early labour }\end{array}$ & $\begin{array}{l}\text { Experimental (Continuous } \\
\text { support by midwife) group } \\
\text { also had a single room, free } \\
\text { movement, food and drink, } \\
\text { explanations, massage, } \\
\text { compresses. } \\
\text { Control group (routine care) } \\
\text { did not have a private room, } \\
\text { did not receive one-to-one } \\
\text { care, were not permitted } \\
\text { food, and did not receive } \\
\text { education and explanation } \\
\text { about the labour process. }\end{array}$ & $\begin{array}{l}\text { Duration of active phase of } \\
\text { labour and second stage, } \\
\text { proportion c-section, } \\
\text { oxytocin use. } \\
\text { Neonatal : Apgar score }<7 \\
\text { at } 5 \text { minutes }\end{array}$ & None (RCT) & $\begin{array}{l}\text { Mean duration of the active phase of labour } \\
(167.9 \pm 76.3 \text { min vs } 247.7 \pm 101 \mathrm{~min}, \mathrm{p}<0.001) \text {, } \\
\text { second stage of labour }(34.9 \pm 25.4 \mathrm{~min} \text { vs } \\
55.3 \pm 33.7 \mathrm{~min}, \mathrm{p}=0.003) \text {, and the number of } \\
\text { caesarean deliveries }(8 \% \text { vs } 24 \%, P=0.03 \text { )were } \\
\text { significantly lower in the intervention group } \\
\text { compared with the control group. The rates of } \\
\text { oxytocin use ( } 22 \% \text { vs } 38 \%, p=0.09 \text { ) and Apgar } \\
\text { scores of less than } 7 \text { at } 5 \text { minutes ( } 0 \% \text { vs } 2 \% \text {, } \\
p=0.29 \text { ) were similar between the two groups }\end{array}$ \\
\hline
\end{tabular}




\begin{tabular}{|c|c|c|c|c|c|c|}
\hline $\begin{array}{l}\text { Author and } \\
\text { date }\end{array}$ & Design & $\begin{array}{l}\text { Participants and } \\
\text { Setting }\end{array}$ & Measurement of staffing & Outcome measures & $\begin{array}{l}\text { Potential confounders } \\
\text { measured and included in } \\
\text { analysis }\end{array}$ & Results \\
\hline $\begin{array}{l}\text { Kim } 2016 \\
\text { (Korea) }\end{array}$ & $\begin{array}{l}\text { Cohort study - } \\
\text { retrospective, } \\
\text { routine data. } \\
\text { Multi centre }\end{array}$ & $\begin{array}{l}633,461 \text { admissions } \\
\text { in obstetrics and } \\
\text { gynaecology, } \\
438,191 \text { were c- } \\
\text { sections. }\end{array}$ & $\begin{array}{l}\text { Hospital level data. The } \\
\text { number of nurses was the } \\
\text { sum of the Registered Nurses } \\
\text { (RNs) and licensed practical } \\
\text { nurses (LPNs) in the hospital. } \\
\text { The proportion of RNs was the } \\
\text { number of RNs among the } \\
\text { total number of nurses } \\
\text { (number of RNs)/(number of } \\
\text { RNs +number of LPNs). }\end{array}$ & $\begin{array}{l}\text { Readmission within } 30 \\
\text { days. } \\
\text { No neonatal outcome } \\
\text { measures }\end{array}$ & $\begin{array}{l}\text { Excluded hospitals with low } \\
\text { inpatient volume (<50 } \\
\text { patients) and excluded tertiary } \\
\text { hospitals which had high } \\
\text { variations in staffing numbers. } \\
\text { Measured age, patient clinical } \\
\text { complexity level and length of } \\
\text { stay but unclear if adjusted for } \\
\text { in the analysis. }\end{array}$ & $\begin{array}{l}\text { For the subgroup analysis of caesarean delivery, } \\
\text { the rate of readmission within } 30 \text { days was } \\
\text { significantly lower as the proportion of RNs } \\
\text { increased (RR } 0.96,95 \% \mathrm{Cl} 0.93 \text { to } 0.98 \text {, } \\
\mathrm{p}=0.0021 \text { ). Total number of nurses was not } \\
\text { associated with the risk of readmission within } 30 \\
\text { days (RR1.01, } 95 \% \mathrm{Cl} 1.0 \text { to } 1.02 \text { ). Also measured } \\
\text { medical staffing. }\end{array}$ \\
\hline $\begin{array}{l}\text { Knape } 2014 \\
\text { (Germany) }\end{array}$ & $\begin{array}{l}\text { Cohort study- } \\
\text { secondary analysis } \\
\text { of a controlled trial } \\
\text { in which the } \\
\text { intervention } \\
\text { midwife led care } \\
\text { was introduced. } \\
\text { Multi centre }\end{array}$ & $\begin{array}{l}\text { 1238 participants, } \\
\text { Women were } \\
\text { eligible for the study } \\
\text { if they had a low-risk } \\
\text { status. Secondary } \\
\text { analysis from } 999 \\
\text { cases where data } \\
\text { available on } \\
\text { attendance of } \\
\text { midwives }\end{array}$ & $\begin{array}{l}\text { workload or midwives } \\
\text { variable dichotomised } \\
\text { whether } 1: 1 \text { care was given } \\
\text { ( } 100 \% \text { or not). }\end{array}$ & $\begin{array}{l}\text { Mode of birth. } \\
\text { No neonatal outcome } \\
\text { measures }\end{array}$ & $\begin{array}{l}\text { Adjusted for parity, length of } \\
\text { stay, epidural use, oxytocin } \\
\text { use, birthweight, childbirth } \\
\text { education class attendance, } \\
\text { age, income, education, } \\
\text { attendance of obstetrician, } \\
\text { presence of students, partner } \\
\text { support and time of admission. }\end{array}$ & $\begin{array}{l}\text { The workload of midwives (1:1 care or }<1: 1 \text { care) } \\
\text { was significantly associated with fewer } \\
\text { caesareans or operative births in univariate } \\
\text { analysis ( } 11 \% \text { vs } 20.1 \%, p=0.01) \text {. These effects } \\
\text { were no longer significant in the multiple logistic } \\
\text { regression when } 19 \text { variables were included } \\
\text { (coefficients and p values not presented for these } \\
\text { variables). }\end{array}$ \\
\hline $\begin{array}{l}\text { Kpea } 2015 \\
\text { (France) }\end{array}$ & $\begin{array}{l}\text { Cross sectional. } \\
\text { Multi centre }\end{array}$ & $\begin{array}{l}\text { Population } 14,681 \\
\text { women in } 535 \\
\text { maternity units. } \\
7558 \text { excluded as } \\
\text { high risk. Study } \\
\text { sample was } 1835 \\
\text { women who } \\
\text { preferred not to } \\
\text { have epidural or } \\
\text { spinal analgesia }\end{array}$ & $\begin{array}{l}\text { Midwifery Workload - ratio of } \\
\text { the number of midwives per } \\
\text { shift in the labour ward to the } \\
\text { number of annual deliveries; } \\
\text { workload was considered high } \\
\text { in the quartile with the lowest } \\
\text { ratio ( } 25 \% \text { of maternity units } \\
\text { with the fewest midwives per } \\
\text { annual deliveries). } \\
\text { Dichotomised as workload } \\
\text { high or not. }\end{array}$ & $\begin{array}{l}\text { Having epidural analgesia } \\
\text { when not previously } \\
\text { planned it. No neonatal } \\
\text { outcome measures }\end{array}$ & $\begin{array}{l}\text { Multiple regression model } \\
\text { included age, parity, education, } \\
\text { living with partner, childbirth } \\
\text { class attendance, adequate } \\
\text { prenatal care, adverse } \\
\text { obstetric history, unfavourable } \\
\text { conditions in current } \\
\text { pregnancy, gestational age, } \\
\text { oxytocin administration, mode } \\
\text { of birth, public/private hospital } \\
\text { and availability of } \\
\text { anaesthetist.. }\end{array}$ & $\begin{array}{l}\text { If high midwifery workload, } 58.3 \% \text { had } \\
\text { epidural/spinal, } 49.7 \% \text { if no high workload, chi-sq } \\
p=0.0007 \text {. The effect remained significant after } \\
\text { adjustment for other factors in the model. High } \\
\text { midwife workload aRR }=1.1 \text { ( } 95 \% \mathrm{Cl}, 1.0-1.2 \text {, } \\
\mathrm{p}=0.03 \text { ) compared to other } 3 \text { quartile which is } \\
\text { absence of high workload. }\end{array}$ \\
\hline
\end{tabular}




\begin{tabular}{|c|c|c|c|c|c|c|}
\hline $\begin{array}{l}\text { Author and } \\
\text { date }\end{array}$ & Design & $\begin{array}{l}\text { Participants and } \\
\text { Setting }\end{array}$ & Measurement of staffing & Outcome measures & $\begin{array}{l}\text { Potential confounders } \\
\text { measured and included in } \\
\text { analysis }\end{array}$ & Results \\
\hline $\begin{array}{l}\text { Makhfudli } \\
2020 \\
\text { (Indonesia) }\end{array}$ & $\begin{array}{l}\text { Cross sectional } \\
\text { Multicentre }\end{array}$ & $\begin{array}{l}8,266 \text { deliveries } \\
\text { from } 11 \text { maternity } \\
\text { unis in } 6 \text { hospitals. } \\
\text { Included only single } \\
\text { live births and } \\
\text { women aged } 15-49 \\
\text { years }\end{array}$ & $\begin{array}{l}\text { Midwife to birth ratio per } \\
\text { year, taken from hospital } \\
\text { database systems }\end{array}$ & $\begin{array}{l}\text { Maternal deaths, near miss } \\
\text { events (Grouped as severe } \\
\text { maternal outcome). } \\
\text { No neonatal outcomes } \\
\text { measured. }\end{array}$ & $\begin{array}{l}\text { Mode of birth, admission } \\
\text { procedure, length of stay, age, } \\
\text { place of residence, obstetric } \\
\text { complications }\end{array}$ & $\begin{array}{l}\text { Women admitted to units with higher midwifery } \\
\text { staffing had an increased odds of having an } \\
\text { severe maternal outcome (OR } 1.81,95 \% \text { (Cl } 1.07 \\
\text { to } 3.06 \text { ). } \\
\text { Women admitted to units with higher nurse } \\
\text { staffing had a decreased odds of a severe } \\
\text { maternal outcome (OR } 0.48,95 \% \mathrm{Cl} 0.31 \text { to } 0.74 \text { ) }\end{array}$ \\
\hline $\begin{array}{l}\text { Mercer } \\
2016 \text { (USA) } \\
\text { Abstract } \\
\text { only }\end{array}$ & $\begin{array}{l}\text { Cohort study } \\
\text { Multicentre }\end{array}$ & $\begin{array}{l}101,120 \text { pregnancies } \\
\text { from } 24 \text { hospitals. } \\
\text { Excluded scheduled } \\
\text { caesarean, those } \\
\text { delivering outside } \\
\text { labour and delivery, } \\
\text { multiple gestations, } \\
\text { and neonatal deaths }\end{array}$ & $\begin{array}{l}\text { Nurse to patient ratio } \\
\text { (Total nursing hours per } \\
\text { shift/births per shift/8 hours) }\end{array}$ & $\begin{array}{l}\text { Postpartum haemorrhage, } \\
\text { Shoulder dystocia, 5-minute } \\
\text { Apgar below 4, Hypoxic } \\
\text { Ischaemic Encephalopathy, } \\
\text { Fetal trauma, and cord pH } \\
\text { below 7.0. }\end{array}$ & $\begin{array}{l}\text { Weekday vs Weekend, Night vs } \\
\text { Day vs Evening shift, Small } \\
\text { (below } 3,500 \text { ) vs Medium } \\
(3,500-5,499) \text { vs Large (above } \\
5,500 \text { ) units }\end{array}$ & $\begin{array}{l}\text { The frequencies of adverse perinatal } \\
\text { complications did not vary with nurse to patient } \\
\text { ratio. Estimate of effect, } \mathrm{Cl} \text { and } \mathrm{p} \text { value not } \\
\text { presented. }\end{array}$ \\
\hline $\begin{array}{l}\text { Mugford } \\
1988 \text { (UK) } \\
\text { Reported } \\
\text { earlier as } \\
\text { Stilwell }\end{array}$ & $\begin{array}{l}\text { Cohort study - } \\
\text { retrospective, } \\
\text { routine data }\end{array}$ & $\begin{array}{l}20 \text { maternity units } \\
\text { providing level } 2 \\
\text { care (consultant } \\
\text { obstetric units with } \\
\text { facilities for sick } \\
\text { neonates). Selected } \\
\text { years 1978, 1980, } \\
1982\end{array}$ & $\begin{array}{l}\text { Number of FTE qualified } \\
\text { midwifery staff per } 1000 \\
\text { births, weighted to take } \\
\text { account of effect on workload } \\
\text { of transfers }\end{array}$ & $\begin{array}{l}\text { No maternal outcome } \\
\text { measures. Stilwell study } \\
\text { extended so mortality } \\
\text { included all neonatal } \\
\text { deaths, both in-house and } \\
\text { after transfer, occurring in } \\
\text { the first month (neonatal } \\
\text { mortality). }\end{array}$ & $\begin{array}{l}\text { Birthweight, paediatric medical } \\
\text { staff, obstetric medical staff, } \\
\text { nursing staff, workload } \\
\text { (admissions, transfers, } \\
\text { deliveries) }\end{array}$ & $\begin{array}{l}\text { Only paediatric medical staffing was related to } \\
\text { neonatal mortality. No other staffing variables } \\
\text { were related to this outcome. p values, } \\
\text { coefficients and Cls not presented }\end{array}$ \\
\hline
\end{tabular}




\begin{tabular}{|c|c|c|c|c|c|c|}
\hline $\begin{array}{l}\text { Author and } \\
\text { date }\end{array}$ & Design & $\begin{array}{l}\text { Participants and } \\
\text { Setting }\end{array}$ & Measurement of staffing & Outcome measures & $\begin{array}{l}\text { Potential confounders } \\
\text { measured and included in } \\
\text { analysis }\end{array}$ & Results \\
\hline $\begin{array}{l}\text { Prapawichar } \\
2020 \\
\text { (Thailand) }\end{array}$ & $\begin{array}{l}\text { Case-control study. } \\
\text { Multi centre }\end{array}$ & $\begin{array}{l}\text { Data from } 14 \\
\text { hospitals. } \\
\text { Cases: } 153 \text { women } \\
\text { with post partum } \\
\text { haemorrhage } \\
\text { following vaginal } \\
\text { delivery } \\
\text { Control: matched } \\
\text { sample of } 1530 \\
\text { without post partum } \\
\text { haemorrhage }\end{array}$ & $\begin{array}{l}\text { Patient to nurse-midwife ratio } \\
\text { for the institution (meeting } \\
\text { standard criteria of } 2: 1 \text { or } \\
\text { not). } \\
\text { Additional category of } \\
\text { number of nurse-midwives > } \\
\text { or < than } 2 \text { per shift - this } \\
\text { does not account for } \\
\text { workload. }\end{array}$ & $\begin{array}{l}\text { Postpartum haemorrhage } \\
\text { (PPH). No neonatal } \\
\text { outcome measures }\end{array}$ & $\begin{array}{l}\text { Maternal factors including } \\
\text { demographic data, age, } \\
\text { reproductive history, parity, } \\
\text { gestational age, anaemia, } \\
\text { twins, gestational diabetes } \\
\text { mellitus, and past history of } \\
\text { postpartum haemorrhage, } \\
\text { method of delivery, health } \\
\text { service factors such as number } \\
\text { of beds, proportion of vaginal } \\
\text { births, and training for PPH } \\
\text { management. }\end{array}$ & $\begin{array}{l}\text { In univariate analysis, the hospitals which had } \\
\text { below the reference nurse-midwife to patient } \\
\text { ratio had significantly increased odds of post } \\
\text { partum haemorrhage (OR } 1.83,95 \% \mathrm{Cl} 1.22 \text { to } \\
2.74 \mathrm{p}=0.016) \text {. } \\
\text { In multivariate analysis, the factor remained } \\
\text { significant OR } 2.31(95 \% \mathrm{Cl} 1.08 \text { to } 4.92, \mathrm{p}=0.03) \text {. }\end{array}$ \\
\hline $\begin{array}{l}\text { Rowe } 2014 \\
\text { (UK) }\end{array}$ & $\begin{array}{l}\text { Secondary analysis } \\
\text { of cohort study. } \\
\text { Multi centre }\end{array}$ & $\begin{array}{l}32,257 \text { women } \\
\text { planning a vaginal } \\
\text { birth in an obstetric } \\
\text { unit. Only low risk } \\
\text { women included }\end{array}$ & $\begin{array}{l}\text { Taken from staffing logs } \\
\text { (available from } 30 \text { units). } \\
\text { Under staffing defined as the } \\
\text { percentage of shifts where } \\
\text { there was less than } 1 \text { midwife } \\
\text { on duty per woman on the } \\
\text { delivery or labour suite. } \\
\text { Staffing data were available } \\
\text { for } 30 \text { of the } 36 \text { obstetric } \\
\text { units. Staffing and activity logs } \\
\text { completed twice daily by } \\
\text { midwives during data } \\
\text { collection for the cohort } \\
\text { study. Not linked to individual } \\
\text { women. }\end{array}$ & $\begin{array}{l}\text { Instrumental birth, } \\
\text { intrapartum c-section, } \\
\text { composite measure of } \\
\text { normal birth (defined as } \\
\text { birth without induction of } \\
\text { labour, epidural or spinal } \\
\text { analgesia, general } \\
\text { anaesthetic, forceps or } \\
\text { ventouse, caesarean } \\
\text { section or episiotomy), } \\
\text { composite measure of } \\
\text { straightforward birth } \\
\text { (defined as birth without } \\
\text { forceps or ventouse, } \\
\text { intrapartum caesarean } \\
\text { section, third or fourth } \\
\text { degree perineal trauma or } \\
\text { blood transfusion). } \\
\text { No neonatal outcome } \\
\text { measures. }\end{array}$ & $\begin{array}{l}\text { Adjusted for maternal } \\
\text { characteristics: maternal age, } \\
\text { ethnicity, English language } \\
\text { fluency, marital status, Index of } \\
\text { Multiple Deprivation quintile, } \\
\text { body mass index and } \\
\text { gestational age, and for the } \\
\text { presence of complicating } \\
\text { conditions identified at the } \\
\text { start of care in labour }\end{array}$ & $\begin{array}{l}\text { There was no significant difference in rates of } \\
\text { normal birth for nulliparous (coeff }-0.01, p=0.89 \text { ) } \\
\text { or multiparous women (coeff } 0.05, p=0.48 \text { ) if } \\
\text { understaffing was present. There was no } \\
\text { significant association between instrumental } \\
\text { delivery and percentage of mid wife under } \\
\text { staffing for nulliparous (coeff } 0.02, p=0.80 \text { ) or } \\
\text { multiparous women (-0.04, } p=0.07 \text { ). } \\
\text { There was a significant association between } \\
\text { midwife under staffing and lower intrapartum } \\
\text { caesarean section rate for nulliparous women } \\
\text { (coeff- } 0.10, p=0.03 \text { ) but not multiparous women } \\
\text { (coeff }-0.05, p=0.11 \text { ). There was a significant } \\
\text { association between percentage of midwife } \\
\text { under staffing and increased straightforward } \\
\text { birth for multiparous women (coeff } 0.08, p=0.01 \text { ) } \\
\text { but not for nulliparous women (coeff } 0.06 \text {, } \\
p=0.31 \text { ). } \\
\text { There was no significant difference in rates of } \\
\text { epidural use for nulliparous (coeff } 0.05, p=0.59 \text { ) } \\
\text { or multiparous women (coeff } 0.00, p=0.94 \text { ) if } \\
\text { understaffing was present. } \\
\text { There was no significant association in rates of } \\
\text { augmentation and percentage of midwife under } \\
\text { staffing for nulliparous (coeff }-0.1, p=0.16 \text { ) or } \\
\text { multiparous women (- }-0.09, p=0.05 \text { ). }\end{array}$ \\
\hline
\end{tabular}




\begin{tabular}{|c|c|c|c|c|c|c|}
\hline $\begin{array}{l}\text { Author and } \\
\text { date }\end{array}$ & Design & $\begin{array}{l}\text { Participants and } \\
\text { Setting }\end{array}$ & Measurement of staffing & Outcome measures & $\begin{array}{l}\text { Potential confounders } \\
\text { measured and included in } \\
\text { analysis }\end{array}$ & Results \\
\hline $\begin{array}{l}\text { Sandall } 2014 \\
\text { (UK) }\end{array}$ & $\begin{array}{l}\text { Cross sectional - } \\
\text { retrospective, } \\
\text { routine data. } \\
\text { Multi centre }\end{array}$ & 656,969 births & $\begin{array}{l}\text { NHS Workforce Statistics. FTE } \\
\text { midwives and maternity } \\
\text { support staff per } 100 \\
\text { maternities, FTE all staff per } \\
100 \text { maternities and skill mix } \\
\text { (doctor/midwife and } \\
\text { midwife/support worker } \\
\text { ratio). }\end{array}$ & $\begin{array}{l}\text { HES data maternity tail. } \\
\text { Delivery with bodily } \\
\text { integrity = delivery without } \\
\text { caesarean, episiotomy, or a } \\
\text { second-, third- or fourth- } \\
\text { degree perineal tear, } \\
\text { uterine damage. } \\
\text { Composite measure healthy } \\
\text { mother =delivery with } \\
\text { bodily integrity, plus no } \\
\text { instrumental birth, no } \\
\text { sepsis, no anaesthetic } \\
\text { complications, home within } \\
2 \text { days, no readmission } \\
\text { within } 28 \text { days, intact } \\
\text { perineum. } \\
\text { Satisfaction. } \\
\text { HES data baby tail - } \\
\text { Composite measure healthy } \\
\text { baby =weight } 2.5-4.5 \mathrm{~kg} \text {, } \\
\text { gestation } 37-42 \text { weeks, live } \\
\text { baby. }\end{array}$ & $\begin{array}{l}\text { Adjustments were made for } \\
\text { background characteristics } \\
\text { (age, parity, ethnicity, index of } \\
\text { multiple deprivation, } \\
\text { geographical location and } \\
\text { region) and clinical risk. Also } \\
\text { adjusted for Trust } \\
\text { characteristics - size, type, } \\
\text { staffing. }\end{array}$ & 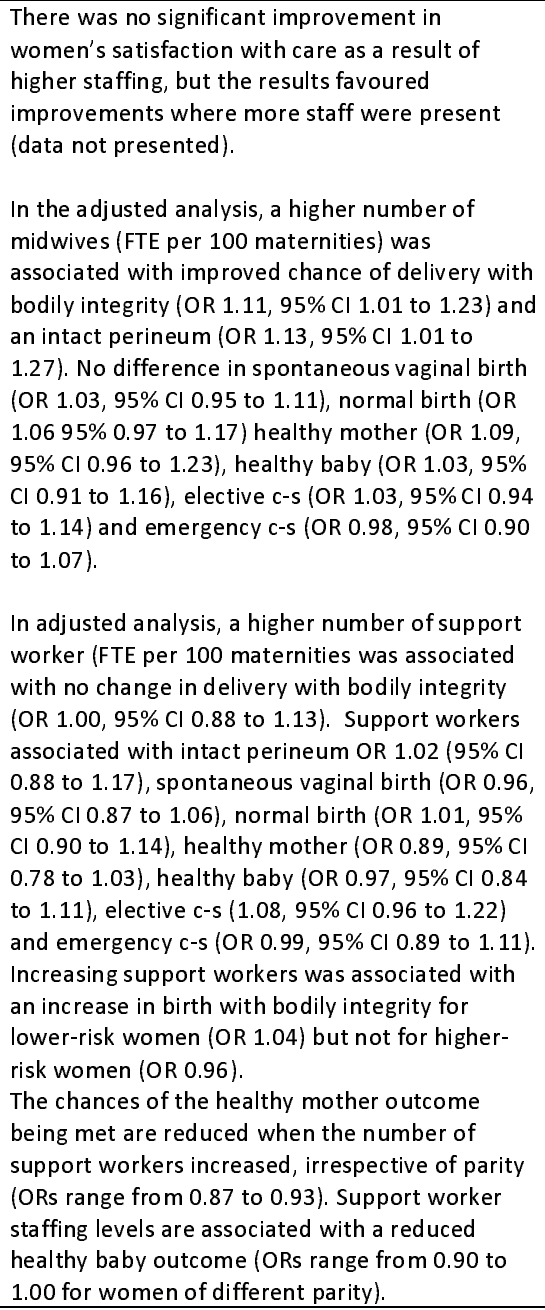 \\
\hline
\end{tabular}




\begin{tabular}{|c|c|c|c|c|c|c|}
\hline $\begin{array}{l}\text { Author and } \\
\text { date }\end{array}$ & Design & $\begin{array}{l}\text { Participants and } \\
\text { Setting }\end{array}$ & Measurement of staffing & Outcome measures & $\begin{array}{l}\text { Potential confounders } \\
\text { measured and included in } \\
\text { analysis }\end{array}$ & Results \\
\hline $\begin{array}{l}\text { Stilwell } 1988 \\
\text { (UK) }\end{array}$ & $\begin{array}{l}\text { Cohort study- } \\
\text { retrospective, } \\
\text { routine data. } \\
\text { Multi centre }\end{array}$ & $\begin{array}{l}20 \text { maternity units } \\
\text { providing level } 2 \\
\text { care (consultant } \\
\text { obstetric units with } \\
\text { facilities for sick } \\
\text { neonates). }\end{array}$ & $\begin{array}{l}\text { Routine data held by each } \\
\text { hospital : FTE numbers of } \\
\text { nursing and midwifery staff } \\
\text { every } 6 \text { months during study. } \\
\text { State certified midwives by } \\
\text { grade, medical staff by grade } \\
\text { in specialities of obstetrics } \\
\text { and paediatrics. Routine } \\
\text { annual data also obtained } \\
\text { from national source. } \\
\text { Number of staff expressed as } \\
\text { a ratio to total births in the } \\
\text { unit. }\end{array}$ & $\begin{array}{l}\text { No maternal outcome } \\
\text { measures. } \\
\text { Stillbirth (death after } 28 \\
\text { weeks of pregnancy), } \\
\text { Early neonatal mortality } \\
\text { (within } 1 \text { week of birth). } \\
\text { Grouped together as } \\
\text { Perinatal Mortality Rate. } \\
\text { Recorded on regional } \\
\text { database or obtained from } \\
\text { hospital. }\end{array}$ & $\begin{array}{l}\text { Analysed low birthweight as } \\
\text { independent variable. } \\
\text { Analysed years separately. } \\
\text { Analysed singleton births and } \\
\text { coded as congenital } \\
\text { malformation separately. } \\
\text { Number of births in each unit } \\
\text { was a weighting factor in } \\
\text { regression analysis. Excluded } \\
\text { GP maternity units and } \\
\text { regional neonatal and obstetric } \\
\text { referral units so sample more } \\
\text { homogenous. }\end{array}$ & $\begin{array}{l}\text { There was no significant correlation between } \\
\text { nursing and midwifery staffing and rate of } \\
\text { perinatal death. The obstetric, midwifery, and } \\
\text { nursing variables were not selected by any of the } \\
\text { regressions ( } p \text { values, coefficients and Cls not } \\
\text { presented) }\end{array}$ \\
\hline $\begin{array}{l}\text { Tucker } 2003 \\
\text { (UK) }\end{array}$ & $\begin{array}{l}\text { Cohort study - } \\
\text { prospective. } \\
\text { Multi centre }\end{array}$ & $\begin{array}{l}1561 \text { consecutively } \\
\text { delivered women } \\
\text { with Continuous } \\
\text { Electronic Fetal } \\
\text { Monitoring (CEFM) } \\
\text { on consultant-led } \\
\text { labour wards. } \\
\text { Excluded multiple } \\
\text { pregnancies and } \\
\text { elective c-sections } \\
\text { and births in } \\
\text { alongside units }\end{array}$ & $\begin{array}{l}\text { Workload log collected } 4 \\
\text { times a day by shift leaders } \\
\text { Measured midwives on duty } \\
\text { and women's measure of } \\
\text { dependency. Workload data } \\
\text { were expressed as unit } \\
\text { occupancy and staffing ratios. } \\
\text { Staffing ratios were the } \\
\text { number of observed midwives } \\
\text { divided by the calculated } \\
\text { required number of midwives } \\
\text { as calculated by Birthrate plus } \\
\text { and two advisory documents. }\end{array}$ & $\begin{array}{l}\text { CEFM use, appropriate } \\
\text { CEFM, time for senior } \\
\text { doctor response to } \\
\text { abnormality. Workload } \\
\text { measured at time of fetal } \\
\text { heart abnormality used in } \\
\text { analysis of this outcome. } \\
\text { Apgar score }<7 \text { at } 5 \\
\text { minutes, admission to } \\
\text { neonatal unit (NNU) }>48 \\
\text { hours, and neonatal } \\
\text { resuscitation. } \\
\text { Data obtained from } \\
\text { national dataset linked to } \\
\text { birth registrations. }\end{array}$ & $\begin{array}{l}\text { Adjusted for maternal } \\
\text { comorbidity from ICD codes, } \\
\text { unit workload at time of } \\
\text { admission. }\end{array}$ & $\begin{array}{l}\text { There were no adjusted associations between } \\
\text { increased staffing and use of appropriate CEFM } \\
\text { commencement for high risk women (OR } 0.90 \text {, } \\
95 \% \mathrm{Cl} 0.63,1.30 \text { ), low risk women (OR } 1.12,95 \% \\
\mathrm{Cl} 0.85,1.47 \text { ) or time lag in senior doctor review } \\
\text { (OR }-7.8 \text { mins, } 95 \% \mathrm{Cl}-52.4,36.8 \text { ). No differences } \\
\text { in Apgar }<7 \text { at } 5 \text { minutes ( } 0.98,95 \% \mathrm{Cl} 0.94 \text {, } \\
1.04 \text { ) or admission to NNU for }>48 \text { hours (OR } \\
0.97,95 \% \mathrm{Cl} 0.95,1.00 \text { ) by staffing ratios (after } \\
\text { adjustment). There was a significant association } \\
\text { between increasing staffing ratios and lower odds } \\
\text { of advanced neonatal resuscitation (excluding } \\
\text { bag and mask only) (0.97, } 95 \% \mathrm{Cl} 0.94 \text { to } 0.99 \text { ). } \\
\text { This was not significant for all resuscitation } \\
\text { measures (OR } 0.98,95 \% \mathrm{Cl} 0.96 \text { to } 1.00 \text { ) }\end{array}$ \\
\hline $\begin{array}{l}\text { Zbiri } 2008 \\
\text { (France) }\end{array}$ & $\begin{array}{l}\text { Cohort study, } \\
\text { retrospective. } \\
\text { Multicentre }\end{array}$ & $\begin{array}{l}102,236 \text { live } \\
\text { deliveries, } \\
\text { representing the } \\
\text { populations giving } \\
\text { birth in } 11 \text { hospitals }\end{array}$ & $\begin{array}{l}\text { Full-time equivalents (FTEs) at } \\
\text { hospital level. All } \\
\text { professionals in the maternity } \\
\text { unit, not those assigned to a } \\
\text { particular ward. The numbers } \\
\text { of FTEs were related to the } \\
\text { total number of deliveries per } \\
\text { year and expressed as } \\
\text { numbers of FTEs per } 100 \\
\text { deliveries. }\end{array}$ & Mode of delivery & $\begin{array}{l}\text { Demographic characteristics } \\
\text { (age, parity, nulliparous or } \\
\text { parous), medical } \\
\text { characteristics or other } \\
\text { pregnancy conditions, hospital } \\
\text { information used and staffing - } \\
\text { number of obstetricians, } \\
\text { anaesthesiologists, and } \\
\text { midwives. }\end{array}$ & $\begin{array}{l}\text { The higher the number of FTE midwives per } 100 \\
\text { deliveries, the lower the probability of elective } \\
\text { caesarean delivery (aOR } 0.79,95 \% \mathrm{Cl} 0.69-0.90 \text {, } \\
\text { p-value }<0.001 \\
\text { Elasticity study : The likelihood of an elective } \\
\text { caesarean delivery would be associated with a } \\
\text { decrease of } 3.4 \text { percentage points if the midwife } \\
\text { levels had increased by } 10 \% \text {. } \\
\text { No significant differences with midwifery staffing } \\
\text { and urgent caesarean aOR } 1.40 \text { ( } 95 \% \mathrm{Cl} 0.76- \\
2.60 \text { ) or intrapartum caesarean aOR } 1.11(95 \% \mathrm{Cl} \\
0.84-1.48 \text { ) }\end{array}$ \\
\hline
\end{tabular}


medRxiv preprint doi: https://doi.org/10.1101/2021.03.27.21254457; this version posted March 29, 2021. The copyright holder for this preprint (which was not certified by peer review) is the author/funder, who has granted medRxiv a license to display the preprint in perpetuity.

All rights reserved. No reuse allowed without permission.

\section{References}

Aiken, L., Sloane, D., Bruyneel, L., et al., 2014. Nurse staffing and education and hospital mortality in nine European countries: a retrospective observational study. Lancet, 383(9931), 1824-1830.

Aiken, L., Sloane, D., Griffiths, P., et al., 2017. Nursing skill mix in European hospitals: cross-sectional study of the association with mortality, patient ratings, and quality of care. BMJ quality \& safety, 26(7), 559-568.

Ashcroft, B., Elstein, M., Boreham, N., et al., 2003. Prospective semistructured observational study to identify risk attributable to staff deployment, training, and updating opportunities for midwives. BMJ, 327(7415), 584.

Association of Women's Health Obstetric Neonatal Nurses, 2010. Guidelines for professional registered nurse staffing for perinatal units Executive Summary. Journal of Obstetric, Gynecologic \& Neonatal Nursing, 40, 131-134.

Australian Nursing Midwifery Foundation, 2015. Nurse/Midwife: Patient ratios-It's a matter of saving lives. Available from https://www.anmfvic.asn.au/ /media/f06f12244fbb4522af619e1d5304d71d.

Bailey, S., Wilson, G., \& Yoong, W., 2015. What factors affect documentation by midwives? A prospective study assessing relationship between length of shift, workload and quality of note keeping. Midwifery, 31(8), 787-792.

Ball, J., \& Washbrook, M., 2015. Safe staffing in midwifery care: Gathering data and learning lessons with Birthrate Plus. The Health Foundation.

https://improve.bmj.com/sites/default/files/resources/3.safe staffing in midwifery care-v3.pdf.

Bazian, 2015. Safe midwifery staffing for maternity settings. The relationship between midwifery staffing at a local level and maternal and neonatal outcomes, and factors affecting these requirements. Available from https://www.nice.org.uk/guidance/ng4/evidence/evidence-review-2pdf-5134718.

Bick, D. E., Sandall, J., Furuta, M., et al., 2014. A national cross sectional survey of heads of midwifery services of uptake, benefits and barriers to use of obstetric early warning systems (EWS) by midwives. Midwifery, 30(11), 1140-1146.

Bohren, M. A., Hofmeyr, G. J., Sakala, C., et al., 2017. Continuous support for women during childbirth. Cochrane database of systematic reviews(7), DOI: 10.1002/14651858.CD14003766.pub14651856.

Care Quality Commission, 2020. 2019 survey of women's experiences of maternity care. Available from https://www.cqc.org.uk/sites/default/files/20200128 mat19 statisticalrelease.pdf.

Cerbinskaite, A., Malone, S., McDermott, J., et al., 2011. Emergency caesarean section: influences on the decision-to-delivery interval. Journal of pregnancy, 2011, doi:10.1155/2011/640379.

Clapp, M. A., James, K. E., Bates, S. V., et al., 2019. Unexpected term NICU admissions: a marker of obstetrical care quality? American journal of obstetrics and gynecology, 220(4), 395. e391-395. e312. 
medRxiv preprint doi: https://doi.org/10.1101/2021.03.27.21254457; this version posted March 29, 2021. The copyright holder for this preprint (which was not certified by peer review) is the author/funder, who has granted medRxiv a license to display the preprint in perpetuity.

All rights reserved. No reuse allowed without permission.

Clark, S. L., Saade, G. A., Meyers, J. A., et al., 2014. The clinical and economic impact of nurse to patient staffing ratios in women receiving intrapartum oxytocin. American journal of perinatology, 31(2), 119-124.

Coffman, J. M., Seago, J. A., \& Spetz, J., 2002. Minimum nurse-to-patient ratios in acute care hospitals in California. Health Affairs, 21(5), 53-64.

Cookson, G., Jones, S., van Vlymen, J., et al., 2014. The Cost-Effectiveness of Midwifery Staffing and Skill Mix on Maternity Outcomes. A Report for the National Institute for Health and Care Excellence. https://www.nice.org.uk/guidance/ng4/evidence/economicevaluation-\%20report-5277277.

Dani, C., Papini, S., lannuzzi, L., et al., 2020. Midwife-to-newborn ratio and neonatal outcome in healthy term infants. Acta Paediatrica, 00(1-4). DOI: 10.1111/apa.15180.

Dent, J., 2020. Shift length and working practices in UK hospital settings: an online survey of Heads of Midwifery. Midwifery, 102709. doi: 10.1016/j.midw.2020.102709.

Dietz, H. P., \& Campbell, S., 2016. Toward normal birth-but at what cost? American journal of obstetrics and gynecology, 215(4), 439-444.

Gagnon, A. J., Waghorn, K., \& Covell, C., 1997. A randomized trial of one-to-one nurse support of women in labor. Birth, 24(2), 71-77.

Gerova, V., 2014. Association between mode of birth, staffing and structural characteristics in NHS trusts with maternity services in England (2010/11). (PhD). King's College London, Retrieved from https://kclpure.kcl.ac.uk/portal/en/theses/association-between-mode-of-birth-staffing-andstructural-characteristics-in-nhs-trusts-with-maternity-services-in-england-201011/05474111-c115$\underline{4 e 7 f-9 c 13-2908 d 8 d 7 f 64 c) \cdot h t m l}$

Gerova, V., Griffiths, P., Jones, S., et al., 2010. The association between midwifery staffing and outcomes in maternity units in England: observational study using routinely collected data. https://eprints. soton.ac.uk/168511/.

Griffin, R., Richardson, M., \& Morris-Thompson, T., 2012. An evaluation of the impact of maternity support workers. British Journal of Midwifery, 20(12), 884-889.

Griffiths, P., Ball, J., Bloor, K., et al., 2018. Nurse staffing levels, missed vital signs and mortality in hospitals: retrospective longitudinal observational study. NIHR Journals Library, 6, ISSN 2050-4349.

Griffiths, P., Maruotti, A., Recio Saucedo, A., et al., 2019. Nurse staffing, nursing assistants and hospital mortality: retrospective longitudinal cohort study. BMJ Qual Saf, 28(8), 609-617.

Haftu, M., Girmay, A., Gebremeskel, M., et al., 2019. Commonly missed nursing cares in the obstetrics and gynecologic wards of Tigray general hospitals; Northern Ethiopia. Plos One, 14(12).

Heinen, M. M., van Achterberg, T., Schwendimann, R., et al., 2013. Nurses' intention to leave their profession: a cross sectional observational study in 10 European countries. International journal of nursing studies, 50(2), 174-184. 
medRxiv preprint doi: https://doi.org/10.1101/2021.03.27.21254457; this version posted March 29, 2021. The copyright holder for this preprint (which was not certified by peer review) is the author/funder, who has granted medRxiv a license to display the preprint in perpetuity.

All rights reserved. No reuse allowed without permission.

Hodnett, E. D., Gates, S., Hofmeyr, G. J., et al., 2013. Continuous support for women during childbirth. Cochrane database of systematic reviews(7), DOI:

10.1002/14651858.CD14003766. pub14651855.

Hodnett, E. D., Lowe, N. K., Hannah, M. E., et al., 2002. Effectiveness of nurses as providers of birth labor support in North American hospitals: a randomized controlled trial. Journal of the American Medical Association, 288(11), 1373-1381.

Hunter, B., Fenwick, J., Sidebotham, M., et al., 2019. Midwives in the United Kingdom: Levels of burnout, depression, anxiety and stress and associated predictors. Midwifery, 79, 102526.

Joyce, R., Webb, R., \& Peacock, J., 2002. Predictors of obstetric intervention rates: case-mix, staffing levels and organisational factors of hospital of birth. Journal of Obstetrics and Gynaecology, 22(6), 618-625.

Joyce, R., Webb, R., \& Peacock, J., 2004. Associations between perinatal interventions and hospital stillbirth rates and neonatal mortality. Archives of Disease in Childhood-Fetal and Neonatal Edition, 89(1), F51-F56.

Karimi, F., Ebrahimipour, H., Hooshmand, E., et al., 2016. Medication Errors and its Contributing Factors among Midwives. Journal of Midwifery and Reproductive Health, 4(4), 748-756.

Kashanian, M., Javadi, F., \& Haghighi, M. M., 2010. Effect of continuous support during labor on duration of labor and rate of cesarean delivery. International Journal of Gynecology \& Obstetrics, 109(3), 198-200.

Kim, S. J., Han, K.-T., Lee, H. J., et al., 2016. Positive effects of medical staffing on readmission within 30 days after discharge: a retrospective analysis of obstetrics and gynecology data. The European Journal of Public Health, 26(6), 935-939.

Kirkup, B., 2015. The report of the Morecambe Bay investigation. Morecambe Bay Investigation. Available from https://www.gov.uk/government/publications/morecambe-bay-investigation-report.

Knape, N., Mayer, H., Schnepp, W., et al., 2014. The association between attendance of midwives and workload of midwives with the mode of birth: secondary analyses in the German healthcare system. BMC Pregnancy \& Childbirth, 14(14), 300.

Kpéa, L., Bonnet, M.-P., Le Ray, C., et al., 2015. Initial Preference for Labor Without Neuraxial Analgesia and Actual Use: Results from a National Survey in France. Anesthesia And Analgesia, 121(3), 759-766.

Laliotis, I., \& Cooksona, G., 2018. Labour productivity and skill mix in maternity services: Evidence from the English NHS. https://www.surrey.ac.uk/sites/default/files/2018-09/dp-no-11-labourproductiviy-skill-mix-maternity-NHS.pdf.

Levac, D., Colquhoun, H., \& O'Brien, K. K., 2010. Scoping studies: advancing the methodology. Implementation science, 5(1), 69.

Lopes, S. C., Guerra-Arias, M., Buchan, J., et al., 2017. A rapid review of the rate of attrition from the health workforce. Human resources for health, 15(1), 1-9. 
medRxiv preprint doi: https://doi.org/10.1101/2021.03.27.21254457; this version posted March 29, 2021. The copyright holder for this preprint (which was not certified by peer review) is the author/funder, who has granted medRxiv a license to display the preprint in perpetuity.

All rights reserved. No reuse allowed without permission.

Makhfudli, M., Efendi, F., Kurniati, A., et al., 2020. Staffing characteristics and their associations with the severe maternal outcomes at Indonesian tertiary hospitals. Journal of nursing and social sciences related to health and illness, In Press.

Manktelow, B., Smith, L., \& Seaton, S., 2017. MBRRACE-UK Perinatal Mortality Surveillance Report. UK Perinatal Deaths for Births from January to December 2014. Leicester: Department of Health Sciences, University of Leicester; 2016. In.

Mercer, B. M., 2016. Delivery volume, nurse staffing and adverse perinatal outcomes. Obstetrics and Gynecology, 127(Supplement 1), 36S-37S.

National Institute for Health and Care Excellence, 2015. Safe midwifery staffing for maternity settings. NICE, London. https://www.nice.org.uk/guidance/ng4/resources/safe-midwifery-staffingfor-maternity-settings-pdf-51040125637.

NHS Digital, 2020. NHS Workforce statistics. Available from from https://digital.nhs.uk/data-andinformation/publications/statistical/nhs-workforce-statistics.

Patrician, P. A., Loan, L., McCarthy, M., et al., 2011. The association of shift-level nurse staffing with adverse patient events. J Nurs Adm, 41(2), 64-70.

https://www.ncbi.nlm.nih.gov/pubmed/21266884.

Prapawichar, P., Ratinthorn, A., Utriyaprasit, K., et al., 2020. Maternal and health service predictors of postpartum hemorrhage across 14 district, general and regional hospitals in Thailand. BMC Pregnancy and Childbirth, 20(1).

Renfrew, M. J., McFadden, A., Bastos, M. H., et al., 2014. Midwifery and quality care: findings from a new evidence-informed framework for maternal and newborn care. The Lancet, 384(9948), 11291145.

Rowe, R. E., Townend, J., Brocklehurst, P., et al., 2014. Service configuration, unit characteristics and variation in intervention rates in a national sample of obstetric units in England: an exploratory analysis. BMJ open, 4(5), e005551.

Royal College of Midwives, 2016. RCM guidance on implementing the NICE safe staffing guideline on midwifery staffing in maternity settings. Available from https://www.rcm.org.uk/media/2369/rcmguidance-on-implementing-the-nice-safe-staffing-guideline-on-midwifery-staffing-in-maternitysettings.pdf.

Royal College of Midwives, 2017. The gathering storm: England's midwifery workforce challenges. Available from https://www.rcm.org.uk/media/2374/the-gathering-storm-england-s-midwiferyworkforce-challenges.pdf.

Royal College of Obstetricians and Gynaecologists, 2007. Safer Childbirth: Minimum standards for the organisation and delivery of care in labour: RCOG.

Sandall, J., Murrells, T., Dodwell, M., et al., 2014. The efficient use of the maternity workforce and the implications for safety and quality in maternity care: a population-based, cross-sectional study. Health Services and Delivery Research, 2(38). 
medRxiv preprint doi: https://doi.org/10.1101/2021.03.27.21254457; this version posted March 29, 2021. The copyright holder for this preprint

(which was not certified by peer review) is the author/funder, who has granted medRxiv a license to display the preprint in perpetuity.

All rights reserved. No reuse allowed without permission.

Sandall, J., Soltani, H., Gates, S., et al., 2016. Midwife-led continuity models versus other models of care for childbearing women. Cochrane Database Syst Rev, 4, CD004667.

Simpson, K. R., \& Lyndon, A., 2017. Consequences of delayed, unfinished, or missed nursing care during labor and birth. The Journal of perinatal \& neonatal nursing, 31(1), 32-40.

Simpson, K. R., Lyndon, A., \& Ruhl, C., 2016. Consequences of inadequate staffing include missed care, potential failure to rescue, and job stress and dissatisfaction. Journal of Obstetric, Gynecologic \& Neonatal Nursing, 45(4), 481-490.

Smith, A. H. K., Dixon, A. L., \& Page, L. A., 2009. Health-care professionals' views about safety in maternity services: a qualitative study. Midwifery, 25(1), 21-31

Staggs, V. S., Knight, J. E., \& Dunton, N., 2012. Understanding unassisted falls: effects of nurse staffing level and nursing staff characteristics. J Nurs Care Qual, 27(3), 194-199.

Stilwell, J., Szczepura, A., \& Mugford, M., 1988. Factors affecting the outcome of maternity care. 1. Relationship between staffing and perinatal deaths at the hospital of birth. Journal of Epidemiology \& Community Health, 42(2), 157-169.

Tingle, J., 2016. Managing clinical negligence litigation and costs in the NHS. British Journal of Nursing, 25(21), 1218-1219.

Tucker, J., Parry, G., Penney, G., et al., 2003. Is midwife workload associated with quality of process of care (continuous electronic fetal monitoring [CEFM]) and neonatal outcome indicators? A prospective study in consultant-led labour wards in Scotland. Paediatric and perinatal epidemiology, 17(4), 369-377.

World Health Organization, 2019. Evaluating the quality of care for severe pregnancy complications. The WHO near-miss approach for maternal health. Available from https://www.who.int/reproductivehealth/topics/maternal_perinatal/nmconcept/en/.

Zbiri, S., Rozenberg, P., Goffinet, F., et al., 2018. Cesarean delivery rate and staffing levels of the maternity unit. PLOS ONE [Electronic Resource], 13(11), e0207379.

Zhou, N., Lu, H., Zhao, H., et al., 2019. Midwifery service and midwifery human resource demand in western China: a cross-sectional study. The Lancet, 394 (Supplement 1), S34. 